\title{
Diverse tick-borne microorganisms identified in free-living ungulates in Slovakia
}

Mária Kazimírová ${ }^{*}$, Zuzana Hamšíková1, Eva Špitalská ${ }^{2}$, Lenka Minichová ${ }^{2}$ Lenka Mahríková1, Radoslav Caban³, Hein Sprong ${ }^{4}$, Manoj Fonville', Leonhard Schnittger ${ }^{5,6}$ and Elena Kocianová ${ }^{2}$

\begin{abstract}
Background: Free-living ungulates are hosts of ixodid ticks and reservoirs of tick-borne microorganisms in central Europe and many regions around the world. Tissue samples and engorged ticks were obtained from roe deer, red deer, fallow deer, mouflon, and wild boar hunted in deciduous forests of south-western Slovakia. DNA isolated from these samples was screened for the presence of tick-borne microorganisms by PCR-based methods.

Results: Ticks were found to infest all examined ungulate species. The principal infesting tick was Ixodes ricinus, identified on $90.4 \%$ of wildlife, and included all developmental stages. Larvae and nymphs of Haemaphysalis concinna were feeding on $9.6 \%$ of wildlife. Two specimens of Dermacentor reticulatus were also identified. Ungulates were positive for A. phagocytophilum and Theileria spp. Anaplasma phagocytophilum was found to infect $96.1 \%$ of cervids, $88.9 \%$ of mouflon, and $28.2 \%$ of wild boar, whereas Theileria spp. was detected only in cervids (94.6\%). Importantly, a high rate of cervids (89\%) showed mixed infections with both these microorganisms. In addition to A. phagocytophilum and Theileria spp., Rickettsia helvetica, R. monacensis, unidentified Rickettsia sp., Coxiella burnetii, "Candidatus Neoehrlichia mikurensis", Borrelia burgdorferi (s.l.) and Babesia venatorum were identified in engorged I. ricinus. Furthermore, A. phagocytophilum, Babesia spp. and Theileria spp. were detected in engorged $H$. concinna. Analysis of 165 rRNA and groEL gene sequences revealed the presence of five and two A. phagocytophilum variants, respectively, among which sequences identified in wild boar showed identity to the sequence of the causative agent of human granulocytic anaplasmosis (HGA). Phylogenetic analysis of Theileria 185 rRNA gene sequences amplified from cervids and engorged I. ricinus ticks segregated jointly with sequences of $T$. capreoli isolates into a moderately supported monophyletic clade.
\end{abstract}

Conclusions: The findings indicate that free-living ungulates are reservoirs for A. phagocytophilum and Theileria spp. and engorged ixodid ticks attached to ungulates are good sentinels for the presence of agents of public and veterinary concern. Further analyses of the A. phagocytophilum genetic variants and Theileria species and their associations with vector ticks and free-living ungulates are required.

Keywords: Wildlife, Tick-borne pathogens, Anaplasma phagocytophilum, Theileria, Slovakia

\footnotetext{
* Correspondence: maria.kazimirova@savba.sk

'Institute of Zoology, Slovak Academy of Sciences, Dúbravská cesta 9, 84506

Bratislava, Slovakia

Full list of author information is available at the end of the article
}

(c) The Author(s). 2018 Open Access This article is distributed under the terms of the Creative Commons Attribution 4.0 International License (http://creativecommons.org/licenses/by/4.0/), which permits unrestricted use, distribution, and reproduction in any medium, provided you give appropriate credit to the original author(s) and the source, provide a link to the Creative Commons license, and indicate if changes were made. The Creative Commons Public Domain Dedication waiver (http://creativecommons.org/publicdomain/zero/1.0/) applies to the data made available in this article, unless otherwise stated. 


\section{Background}

In the northern hemisphere, the majority of vector-borne diseases are caused by tick-borne pathogens [1-4]. Ixodes ricinus is a highly competent vector for a variety of disease agents in humans as well as in livestock, such as viruses, bacteria and protozoan parasites [5-7]. Also, the bites of $I$. ricinus by themselves can cause meat allergy [8]. Ixodes ricinus is a generalist tick that infests more than 300 different vertebrate species [9], including birds, lizards, small rodents, hares, hedgehogs as well as free-living ruminants, carnivores or wild boar. It has a three-host life-cycle with larvae feeding predominantly on small mammals or birds, nymphs feeding on small as well as large mammals, and adults preferring larger mammals [10]. Ixodes ricinus is usually associated with deciduous and mixed forests, but recent studies have shown that its populations can also be abundant in green periurban and urban areas [7].

Free-living ungulates are essential feeding hosts for $I$. ricinus and play a vital role in the propagation of this species [11-15]. In addition, they are reservoirs of tick-borne microorganisms some of which may cause disease in humans and domestic animals [7, 16-18]. Knowledge of the tick-borne pathogen reservoir role of wildlife is a prerequisite for a thorough understanding of the epidemiology of tick-borne zoonotic diseases and the development of effective control measures.

The epidemiology of the obligate intracellular bacterium Anaplasma phagocytophilum, the causative agent of tick-borne fever in ruminants and human granulocytic anaplasmosis (HGA), is very complex in Europe, with various ecotypes involved in different epidemiological cycles $[19,20]$. Presence of diverse $A$. phagocytophilum genetic variants has been reported in a wide range of free-living and domestic animals [21-25]. Among them, cervids have been suggested as reservoirs for several $A$. phagocytophilum variants transmitted by $I$. ricinus. Variants associated with roe deer (Capreolus capreolus) are probably non-pathogenic to humans, dogs, horses or domestic ruminants, whereas red deer (Cervus elaphus) is likely a reservoir for variants pathogenic to domestic ruminants and horses $[20,26,27]$. The role of wild boar (Sus scrofa) in the transmission cycle of $A$. phagocytophilum is still unclear. Recent molecular studies have shown that $A$. phagocytophilum genetic variants infecting wild boars and humans clustered together [26, 28, 29]. However, the short duration of infection and, as compared to deer species, the relatively low number of ticks feeding on them, question wild boar as a relevant reservoir host [30].

Wildlife is a potential source of infection with piroplasmids Babesia spp. and/or Theileria spp. Zoonotic species of Babesia, including $B$. divergens and B. venatorum, are transmitted by I. ricinus and have been reported in European cervids [31, 32]. It should be noted, however, that reports on the occurrence of $B$. divergens previous to its exact sequence definition by Malandrin et al. [33] have to be taken with caution as this species is highly similar to $B$. capreoli. Babesia divergens causes babesiosis in cattle and immunocompromised humans [32, 34], whereas B. capreoli, prevalent in roe deer, is non-pathogenic in domestic ruminants [33, 35]. Besides $B$. divergens, B. venatorum (formerly Babesia sp. EU1) has been found to cause disease in humans [36, 37]. Its presence has been confirmed in cervids in many European countries [32, 38-42], and recently in caprines [39] and mouflon [42]. Also, the non-zoonotic B. odocoilei-like taxon, Babesia sp. MO1 and Babesia sp. $\mathrm{CH} 1$, have been detected in cervids [39, 42, 43], and B. motasi, transmitted by Haemaphysalis spp. ticks and causing disease in sheep and goat [44], has been reported in free-living caprines [39].

In Europe, asymptomatic infections caused by piroplasmids of the genus Theileria such as T. capreoli isolates Theileria sp. 3185/02 and Theileria BAB1158 and Theileria spp. isolate Theileria sp. OT3 obtained from roe deer, red deer, and chamois, and Theileria sp. ZS TO4 isolated from red deer have been described in several free-living cervids and caprines [42, 45-52]. Up to now, none of these Theileria species have been described to cause zoonotic disease [32]. Their vectors have not been confirmed in central Europe, but probably I. ricinus and/or Haemaphysalis spp. ticks are involved in their transmission [48-50].

Free-living ruminants may be involved in the epidemiology of $\mathrm{Q}$ fever by maintaining Coxiella burnetii, whereby ticks might also play a role in the circulation of the agent and its transmission from wildlife to domestic animals [53-56]. However, the role of free-living ungulates in the epidemiology of C. burnetii may differ between ecosystems and geographic areas [56].

In contrast, free-living ungulates are likely not reservoirs for Rickettsia spp. of the spotted fever group (SFG) and Borrelia burgdorferi (s.l.), even though the presence of DNA specific for these bacteria have been sporadically detected in their tissues [57-60]. It is assumed that due to complement-mediated killing, the presence of $B$. burgdorferi (s.l.) in ticks feeding on cervids and wild boar is reduced [61-63].

The aims of the present study were to (i) increase the knowledge on the diversity of tick-borne bacteria and piroplasmids infecting free-living ungulates, and (ii) investigate the role of free-living ungulates as carriers of infected ticks and/or reservoirs of tick-borne pathogens in Slovakia, central Europe.

\section{Methods}

Study area and biological samples

Tissue samples and ticks were obtained from a total of 92 gunshot game animals of five species. Forty-four cervids 
comprised of the three species: roe deer (Capreolus capreolus; $n=14$ ), red deer (Cervus elaphus; $n=8$ ) and fallow deer (Dama dama; $n=22$ ). The remaining two species were mouflon (Ovis musimon; $n=9$ ) and wild boar (Sus scrofa; $n=39$ ). Animals were shot by hunters and samples were kindly provided during the legal hunting seasons of 2011-2014 in hunting districts located in deciduous forests of the Small Carpathian Mountains (southwestern Slovakia) (Additional file 1: Figure S1). The mountains are, in part, densely forested, with average annual temperatures of $7-9{ }^{\circ} \mathrm{C}$ and an annual rainfall of 650-690 mm. Sessile oak (Quercus petraea) and European hornbeam (Carpinus betulus) dominate at lower, whereas European beech (Fagus sylvatica) dominate at higher altitudes [64]. The highest mountain peak reaches an elevation of 768 metres above sea level (masl).

The biological samples contained spleen from all hunted specimens, blood, lower parts of legs with skin and hoofs, and engorged and/or unattached ticks. Tick larvae and nymphs were predominantly collected from lower parts of legs and hoofs of cervids. Engorged nymphs and adults attached to other body parts were collected only from three fallow deer individuals whose whole skins were available. After sampling, tissues and ticks were preserved in $70 \%$ ethanol. Information on sex and age could not be obtained for all hunted animals and was therefore not considered in the subsequent analyses. The species, developmental stage, and gender were identified for each tick under a stereomicroscope according to Siuda [65].

\section{DNA isolation}

Genomic DNA was isolated from subsamples of spleen, blood, and from a randomly selected collection of ticks including $I$. ricinus larvae that have been sampled in pools, and I. ricinus nymphs and adults and Haemaphysalis concinna larvae and nymphs that have all been sampled individually. Whenever available, at least five specimens of each tick species and developmental stage were used to isolate genomic DNA by applying the Macherey-Nagel NucleoSpin ${ }^{\circ}$ Tissue kit (Düren, Germany) following the instructions of the manufacturer. Quantity and quality of the isolated DNA were measured with a Nanodrop 2000c spectrophotometer and samples were stored at $-20{ }^{\circ} \mathrm{C}$ for further analyses.

\section{PCR detection of microorganisms}

Samples were screened for the presence of DNA specific for the tested microorganisms by using polymerase chain reaction (PCR)-based assays. A real-time PCR targeting a 77-bp long fragment of the $m s p 2$ gene of $A$. phagocytophilum was performed according to Courtney et al. [66] as described in Svitálková et al. [67]. To identify $A$. phagocytophilum variants, two positive samples from each ungulate species and 16 randomly selected DNA samples of engorged I. ricinus larvae were further analysed by a nested PCR and quantitative real-time PCR (qPCR), respectively, with primers targeting a 546-bp fragment of the $16 S$ rRNA gene $[68,69]$ and a 530-bp fragment of the groEL gene [70]. A 99-bp fragment of the "Candidatus Neoehrlichia mikurensis" groEL gene was amplified with a qPCR [71-73]. A PCR targeting the com1 gene encoding a $27-\mathrm{kDa}$ outer membrane-associated immunoreactive protein was applied for the detection of $C$. burnetii [74]. Rickettsia spp. were detected by amplifying a 381-bp fragment of the gltA gene using genus-specific primers [75, 76]. The presence of B. burgdorferi (s.l.) DNA was detected by amplification of the 5S-23S (rrfA-rrlB) intergenic spacer and identification of Borrelia genospecies was done using a restriction fragment length polymorphism (RFLP) assay [77]. Amplification of a 450-bp region of the $18 S$ rRNA gene of Babesia/Theileria was carried out by PCR following the protocols of Casati et al. [78] and Hamšíková et al. [79]. A duplex qPCR targeting a 62-bp long fragment of the $18 S$ rRNA gene [80] and a 104-bp fragment of an internal transcribed spacer (ITS) region was performed for the detection of Babesia spp.

All primers and probes used in the PCR reactions and the respective references are listed in Additional file 2: Table S1.

\section{Sequence analysis}

Amplicons derived from randomly selected samples positive for Rickettsia and Babesia/Theileria and those for the partial $16 S$ rRNA and groEL genes of A. phagocytophilum were purified and analysed by sequencing using forward and reverse PCR primers (Macrogen, Amsterdam, Netherland). Nucleotide sequences were manually edited using the MEGA6 software [81]. Determined sequences of $A$. phagocytophilum, Babesia spp. and Theileria spp. were deposited in the GenBank database (Additional file 2: Tables S2, S3).

\section{Phylogenetic analysis}

For the phylogenetic analysis of Babesia parasite sequences, a multiple alignment of determined and related $18 S$ rRNA gene sequences available on GenBank using ClustalW was done for piroplasmids pertaining to Babesia (sensu stricto) (Clade VI as defined in [31]). The alignment length comprised of $459 \mathrm{bp}$ and consisted of 39 sequences including T. annulata as outgroup. Gaps were eliminated to result in a final alignment of 403 positions. The evolutionary distance was estimated using the $\mathrm{K} 2+\mathrm{G}$ model with $\mathrm{G}=0.36$ to generate $\mathrm{a}$ neighbour-joining tree [82, 83]. For the phylogenetic analysis of Theileria parasite sequences, a multiple alignment of determined and related $18 S$ rRNA gene sequences available on GenBank using ClustalW was done for piroplasmids pertaining to Theileria (sensu stricto) 
(Clade V as defined in [31]) infecting large ruminants. The alignment length comprised of $464 \mathrm{bp}$ and consisted of 39 sequences including T. equi as outgroup. Gaps were eliminated to result in a final alignment of 443 positions. The $\mathrm{K} 2+\mathrm{G}$ model with $\mathrm{G}=0.66$ was used to generate a neighbour-joining tree [82, 83]. For alignment and phylogenetic analysis, the MEGA6 software was used [81].

Anaplasma phagocytophilum groEL gene sequences were aligned using MUSCLE. For phylogenetic analysis, 55 sequences were used: 12 from this study (see Additional file 2: Table S2), 42 from different European sources available on GenBank, and Anaplasma marginale (GenBank: AF165812) as the outgroup. The evolutionary history was inferred by using the Maximum Likelihood method based on the Tamura 3-parameter model [84]. Positions containing gaps and missing data were eliminated, and there were 464 positions in the final dataset. Alignment and evolutionary analyses were conducted in MEGA X [85].

\section{Statistical analysis}

Infection rates for pooled samples of I. ricinus larvae were analysed by the maximum likelihood estimation (MLE) method according to Biggerstaff et al. [86]. Chi-square test was used to analyse differences in $A$. phagocytophilum and Theileria spp. infection rates in game species, in I. ricinus feeding on cervids, and in tick developmental stages. Furthermore, this test was applied to evaluate differences in single and co-infection rates between developmental stages of I. ricinus and between ticks originating from different cervid hosts. Results on the prevalence of $A$. phagocytophilum and Theileria spp. in I. ricinus attached to cervids were used to calculate the probability of co-infections with the two microorganisms by Chi-square test. $P<0.05$ was considered significant in all statistical analyses. Analyses were performed by using PAST Version 3.19. [87].

\section{Results}

\section{Infection rates in ungulates}

Theileria spp. were found to infect exclusively cervids, whereas A. phagocytophilum, besides cervids, also infected mouflon and wild boar (Table 1). Infections with other tick-borne microorganisms were not detected in any of the examined animals. Infection rates with $A$. phagocytophilum significantly differed when cervids, mouflon, and wild boar were compared (Table 1), but no significant difference was found between cervids and mouflon $\left(\chi^{2}=1.090 ; P=0.780\right)$. The total infection rates with Theileria spp. did not significantly differ between cervid species; however, spleen of red deer was significantly less infected than in roe deer and fallow deer (Table 1). Mixed infections with A. phagocytophilum and
Theileria spp. were detected in $89.8 \%$ of cervids (average co-infection rate for all species), but the differences in co-infection rates between individual cervid species were not significant (Table 1).

\section{Ticks infesting ungulates and their infection with tick-borne microorganisms}

In total, 2660 I. ricinus (2106 larvae, 413 nymphs, 118 females and 23 males), $284 \mathrm{H}$. concinna (241 larvae and 43 nymphs) and 2 Dermacentor reticulatus (1 nymph and 1 male) were collected from $42.4 \%$ (39/92) of the examined animals. All studied ungulate species harboured ticks: red deer $(62.5 \%)$, roe deer $(71.4 \%)$, fallow deer (77.3\%), mouflon (55.5\%), and wild boar (5.1\%) (Table 2). Tick infestation was observed in roe deer, red deer, fallow deer and mouflon in May and from July to December. No ticks were collected in February, April, and June when only samples from wild boars were available. The majority of wild boars were tick-free, except for two individuals, one carrying an I. ricinus nymph and the other a D. reticulatus male. The highest number of ticks was found on a fallow deer shot in August 2014 in the district Rača, Bratislava and included 800 I. ricinus (777 larvae and 23 nymphs) and $215 \mathrm{H}$. concinna (182 larvae and 33 nymphs).

A selection of ticks (22.9\%; 674/2946) (I. ricinus: 371 larvae in 74 pools, 177 nymphs, 72 females, 21 males; $H$. concinna: 19 larvae, 14 nymphs) were analysed for the presence of tick-borne microorganisms. In total, $82.8 \%$ of the samples were infected with at least one microorganism. The diversity of microorganisms in engorged ticks was higher than in the ungulate hosts (Table 3). In addition to $A$. phagocytophilum and Theileria spp., Rickettsia spp., C. burnetii, B. venatorum, "Ca. N. mikurensis" and B. burgdorferi (s.l.) were detected in I. ricinus ticks. Haemaphysalis concinna were infected with $A$. phagocytophilum, Babesia spp. and Theileria spp.

Anaplasma phagocytophilum was detected in all developmental stages of $I$. ricinus collected from cervids and mouflon, and in a few engorged H. concinna larvae from roe deer and fallow deer. Prevalence of infection in $I$. ricinus originating from different hosts varied (Table 3), but the differences were not significant for any of the tick developmental stages (ticks from mouflon were not included in the analyses). The overall prevalence in larvae was $27.7 \%$ MLE, in nymphs and adults it was $59.3 \%$ and $90.3 \%$, respectively, but the differences between the tick stages were not significant. Larvae infected with $A$. phagocytophilum were collected only from hosts that tested positive for $A$. phagocytophilum (4 roe deer, 3 red deer, 11 fallow deer and 4 mouflon). Similarly, infected nymphs originated only from infected hosts (5 roe deer, 4 red deer, 9 fallow deer and 1 mouflon). Infected tick females fed on infected animals ( 1 roe deer, 4 red deer, 
Table 1 Molecular detection of tick-borne microorganisms in spleen and blood of free-living ungulates. Values represent numbers of positive/examined samples and infection rates (\%)

\begin{tabular}{|c|c|c|c|c|c|c|c|}
\hline & Capreolus capreolus & Cervus elaphus & Dama dama & Ovis musimon & Sus scrofa & $x^{2}$-value & $P$-value ${ }^{a}$ \\
\hline \multicolumn{8}{|c|}{ Total infection (spleen and/or blood) } \\
\hline A. phagocytophilum & 13/14 (92.9) & $8 / 8(100)$ & 21/22 (95.4) & $8 / 9(88.9)$ & $11 / 39(28.2)$ & 44.244 & $<0.001$ \\
\hline Theileria sp. & 13/14 (92.9) & $8 / 8(100)$ & 20/22 (90.9) & & & 0.767 & ns \\
\hline Mixed infection & 11/14 (78.6) & $8 / 8(100)$ & 20/22 (90.9) & & & 2.546 & ns \\
\hline \multicolumn{8}{|l|}{ Spleen } \\
\hline A. phagocytophilum & $12 / 14(85.7)$ & 8/8 (100) & 20/22 (90.9) & $6 / 9(66.7)$ & 10/39 (25.6) & 37.553 & $<0.001$ \\
\hline Theileria sp. & $12 / 14(85.7)$ & $3 / 8(37.5)$ & 18/22 (81.8) & & & 7.403 & $<0.05$ \\
\hline Mixed infection & 11/14 (78.6) & $3 / 8(37.5)$ & 17/22 (77.3) & & & 5.108 & ns \\
\hline \multicolumn{8}{|l|}{ Blood $^{b}$} \\
\hline A. phagocytophilum & $6 / 12(50.0)$ & 8/8 (100) & $16 / 17(94.1)$ & $4 / 7(57.1)$ & 6/31 (19.3) & 21.836 & $<0.001$ \\
\hline Theileria sp. & $8 / 12(66.7)$ & $8 / 8(100)$ & 15/17 (88.2) & & & 4.384 & ns \\
\hline Mixed infection & $6 / 12(50)$ & $8 / 8(100)$ & $14 / 17(82.3)$ & & & 7.281 & $<0.05$ \\
\hline \multicolumn{8}{|l|}{ Spleen and blood ${ }^{b}$} \\
\hline A. phagocytophilum & $6 / 12(50.0)$ & 8/8 (100) & $16 / 17(94.1)$ & $3 / 7(42.8)$ & $5 / 31(16.1)$ & 35.597 & $<0.001$ \\
\hline Theileria sp. & $8 / 12(66.7)$ & $3 / 8(37.5)$ & 15/17 (88.2) & & & 6.813 & $<0.05$ \\
\hline Mixed infection & 4/12 (33.3) & $3 / 8(37.5)$ & $11 / 17(64.7)$ & & & 3.279 & ns \\
\hline
\end{tabular}

Abbreviation: ns, not significant

a Prevalence of $A$. phagocytopilum was compared between all examined ungulate species whereas the prevalence of Theileria sp. was compared between the three cervid species

${ }^{\mathrm{b}}$ Blood was not available from all animals

14 fallow deer and 3 mouflon), but were also collected from an uninfected fallow deer. All A. phagocytophilum-positive H. concinna larvae fed on infected cervids.

Rickettsia spp. were detected exclusively in all developmental stages of I. ricinus (Table 3). Total prevalence

Table 2 Numbers of collected ticks and prevalence of infestation of free-living ungulates in the Small Carpathian Mountains (southwestern Slovakia) (2011-2014)

\begin{tabular}{lll}
\hline & $\begin{array}{l}\text { Infested/examined } \\
\text { (prevalence in \%) }\end{array}$ & Tick species and no. of ticks \\
\hline Capreolus capreolus & $10 / 14(71.4)$ & Ir: $618 \mathrm{~L}, 68 \mathrm{~N}, 3 \mathrm{~F}, 1 \mathrm{M}$ \\
& & Hc: $57 \mathrm{~L}, 9 \mathrm{~N}$ \\
Cervus elaphus & $5 / 8(62.5)$ & Ir: $55 \mathrm{~L}, 30 \mathrm{~N}, 8 \mathrm{~F}, 3 \mathrm{M}$ \\
Dama dama & $17 / 22(77.3)$ & Ir: $1422 \mathrm{~L}, 313 \mathrm{~N}, 103 \mathrm{~F}, 18 \mathrm{M}$ \\
& & Hc: $183 \mathrm{~L}, 34 \mathrm{~N}$ \\
& & Dr: $1 \mathrm{~L}$ \\
Ovis musimon & $5 / 9(55.5)$ & Ir: $11 \mathrm{~L}, 1 \mathrm{~N}, 4 \mathrm{~F}, 1 \mathrm{M}$ \\
& & Hc: $1 \mathrm{~L}$ \\
Sus scrofa & Ir: $1 \mathrm{~N}$ \\
& Dr: $1 \mathrm{M}$ \\
Total & & Ir: $2106 \mathrm{~L}, 413 \mathrm{~N}, 118 \mathrm{~F}, 23 \mathrm{M}$ \\
& & Hc: $241 \mathrm{~L}, 43 \mathrm{~N}$ \\
& & Dr: $1 \mathrm{~L}, 1 \mathrm{M}$
\end{tabular}

Abbreviations: Ir, Ixodes ricinus; Hc, Haemaphysalis concinna; Dr, Dermacentor reticulatus; $L$, larva; $N$, nymph; $F$, female; $M$, male was $6.8 \%$ (MLE), $7.3 \%$ and $11.8 \%$ in larvae, nymphs and adults, respectively. Rickettsia-infected ticks were obtained from five roe deer, one red deer, 11 fallow deer and one mouflon. In 27 of 46 tick samples, the Rickettsia species could be identified either as $R$. helvetica (25 samples) or $R$. monacensis (2 samples), while from the remaining 19 samples the Rickettsia species was not determined to species level.

Coxiella burnetii was identified in four I. ricinus nymphs feeding on a roe deer (shot in September 2013), in a pool of larvae and one female from a fallow deer, and in one female from a mouflon (both shot in November 2013) (Table 3).

"Candidatus N. mikurensis" was detected in an engorged I. ricinus nymph and three females collected from roe deer and fallow deer (Table 3).

Borrelia valaisiana was detected in a pool of $I$. ricinus larvae attached to a roe deer and in a nymph and a male from fallow deer. Borrelia afzelii was detected in a nymph from roe deer and Borrelia garinii in two nymphs, one from roe and one from fallow deer (Table 3).

Babesia venatorum (Fig. 1) was detected in three pools of $I$. ricinus larvae which each had been collected from different roe deer individuals, and in a tick female from a fallow deer. Haemaphysalis concinna larvae that fed on a roe deer and a mouflon each harboured another Babesia isolate identified as B. motasi (Fig. 1, Table 3). 
Table 3 Diversity of tick-borne microorganisms in Ixodes ricinus and Haemaphysalis concinna ticks infesting free-living ungulates. Values represent numbers of positive/examined tick samples and prevalence (in \%)

\begin{tabular}{|c|c|c|c|c|c|}
\hline Tick/Host & Capreolus capreolus & Cervus elaphus & Dama dama & Ovis musimon & Sus scrofa \\
\hline \multicolumn{6}{|l|}{ (i) Ixodes ricinus } \\
\hline \multicolumn{6}{|l|}{ Larvae } \\
\hline Anaplasma phagocytophilum & $25 / 31(27.7)^{\mathrm{a}} ; 4^{\mathrm{b}}$ & $5 / 6(23.0)^{a} ; 3^{b}$ & $24 / 32(22.0)^{\mathrm{a}} ; 11^{\mathrm{b}}$ & $5 / 5(57.1)^{\mathrm{a}} ; 4^{\mathrm{b}}$ & \\
\hline Rickettsia sp. & $14 / 31(11.6)^{a}$ & & $1 / 32(0.6)^{\mathrm{a}}$ & & \\
\hline Rickettsia helvetica & $1 / 31(0.7)^{a}$ & $1 / 6(3.1)^{\mathrm{a}}$ & $3 / 32(1.7)^{\mathrm{a}}$ & & \\
\hline Rickettsia monacensis & & & $2 / 3(21.2)^{a}$ & & \\
\hline Coxiella burnetii & & & $1 / 32(0.6)^{a}$ & & \\
\hline Babesia venatorum & $3 / 31(2.1)^{\mathrm{a}}$ & & & & \\
\hline Theileria sp. & $19 / 31(17.7)^{\mathrm{a}} ; 7^{\mathrm{b}}$ & $1 / 6(3.1)^{\mathrm{a}} ; 1^{\mathrm{b}}$ & $11 / 32(8.3)^{\mathrm{a}} ; 8^{\mathrm{b}}$ & & \\
\hline Borrelia valaisiana & $1 / 31(0.75)^{a}$ & & & & \\
\hline No. of animals infested with larvae & 7 & 3 & 13 & 4 & 0 \\
\hline \multicolumn{6}{|l|}{ Nymphs } \\
\hline Anaplasma phagocytophilum & $30 / 59(50.9) ; 5^{b}$ & $12 / 15(80.0) ; 4^{b}$ & $62 / 101(61.4) ; 9^{b}$ & $1 / 1(100) ; 1^{b}$ & \\
\hline Rickettsia sp. & 2/59 (3.4) & $1 / 15(6.7)$ & & & \\
\hline Rickettsia helvetica & 2/59 (3.4) & & 8/101 (7.9) & & \\
\hline Coxiella burnetii & $4 / 59(6.8)$ & & & & \\
\hline CNM & $1 / 59(1.7)$ & & & & \\
\hline Theileria sp. & $17 / 59(28.8) ; 7^{b}$ & $9 / 15(60.0) ; 1^{b}$ & $22 / 101(21.8) ; 10^{\mathrm{b}}$ & & \\
\hline Borrelia valaisiana & & & 1/101 (1.0) & & \\
\hline Borrelia afzelii & $1 / 59(1.7)$ & & & & \\
\hline Borrelia garinii & $1 / 59(1.7)$ & & $1 / 101(1.0)$ & & \\
\hline No. of animals infested with nymphs & 9 & 4 & 12 & 1 & 1 \\
\hline \multicolumn{6}{|l|}{ Females } \\
\hline Anaplasma phagocytophilum & $2 / 3(66.7) ; 1^{\mathrm{b}}$ & $7 / 7(100) ; 4^{b}$ & $54 / 58(93.1) ; 14^{\mathrm{b}}$ & $4 / 4(100) ; 3^{b}$ & \\
\hline Rickettsia helvetica & & & 8/58 (13.8) & $1 / 4(25.0)$ & \\
\hline Coxiella burnetii & & & $1 / 58(1.7)$ & $1 / 4(25.0)$ & \\
\hline CNM & $2 / 3(66.7)$ & & $1 / 58(1.7)$ & & \\
\hline Babesia venatorum & & & $1 / 58(1.7)$ & & \\
\hline Theileria sp. & $2 / 3(66.7) ; 2^{\mathrm{b}}$ & $3 / 7(42.9) ; 3^{b}$ & $39 / 58(67.2) ; 11^{\mathrm{b}}$ & & \\
\hline No. of animals infested with females & 2 & 4 & 15 & 3 & 0 \\
\hline \multicolumn{6}{|l|}{ Males } \\
\hline Anaplasma phagocytophilum & $1 / 1(100) ; 1^{b}$ & $2 / 3(66.7) ; 1^{\mathrm{b}}$ & $13 / 16(81.2) ; 7^{b}$ & $1 / 1(100) ; 1^{b}$ & \\
\hline Rickettsia sp. & $1 / 1(100)$ & & & & \\
\hline Rickettsia helvetica & & & $1 / 16(6.2)$ & & \\
\hline Theileria sp. & $0 / 1(0) ; 0$ & $1 / 3(33.3) ; 1^{b}$ & $8 / 16(50.0) ; 4^{b}$ & & \\
\hline Borrelia valaisiana & & & $1 / 16(6.2)$ & & \\
\hline No. of animals infested with males & 1 & 1 & 8 & 1 & 0 \\
\hline \multicolumn{6}{|l|}{ (ii) Haemaphysalis concinna } \\
\hline \multicolumn{6}{|l|}{ Larvae } \\
\hline Anaplasma phagocytophilum & $2 / 12(16.7) ; 2^{b}$ & & $2 / 6(33.3) ; 1^{\mathrm{b}}$ & $1 / 1(100) ; 1^{b}$ & \\
\hline Babesia sp. & $2 / 12(16.7)$ & & & $1 / 1(100)$ & \\
\hline No. of animals infested with larvae & 5 & 0 & 2 & 1 & 0 \\
\hline
\end{tabular}


Table 3 Diversity of tick-borne microorganisms in Ixodes ricinus and Haemaphysalis concinna ticks infesting free-living ungulates. Values represent numbers of positive/examined tick samples and prevalence (in \%) (Continued)

\begin{tabular}{lllll}
\hline Tick/Host & Capreolus capreolus & Cervus elaphus & Dama dama & Ovis musimon \\
\hline Nymphs & & & & Sus scrofa \\
Theileria $\mathrm{sp}$. & $5 / 14(35.7) ; 2^{\mathrm{b}}$ & & 2 & 0 \\
No. of animals infested with nymphs & 2 & 0 & 0
\end{tabular}

Abbreviation: CNM, "Candidatus Neoehrlichia mikurensis"

${ }^{a} \mathrm{MLE}$, maximum likelihood estimation of infection prevalence

${ }^{\mathrm{b}}$ Numbers of $A$. phagocytophilum- or Theileria sp.-positive ungulates from which infected ticks were collected

Theileria spp. were present in all developmental stages of I. ricinus and in H. concinna nymphs (Table 3). Ticks that tested positive for Theileria spp. fed exclusively on Theileria-infected cervids. Total prevalence was $12.1 \%$ (MLE), $27.1 \%$, and $58.1 \%$ in I. ricinus larvae, nymphs, and adults, respectively. Differences in the prevalence of infected ticks from the three cervid species were significant for larvae $\left(\chi^{2}=6.731, P=0.034\right)$ and nymphs $\left(\chi^{2}=\right.$ 9.669, $P=0.008$ ). Infected larvae were collected from seven roe deer, one red deer and eight fallow deer. Infected nymphs originated from seven roe deer, one red deer and ten fallow deer. Infected females were collected from two roe deer, three red deer and 11 fallow deer. Theileria-positive H. concinna nymphs fed on two infected roe deer individuals.

\section{Mixed infections in ticks}

Mixed infections with two to four different microorganisms were found in $38.4 \%$ of $I$. ricinus samples (48.6\% larval pools, $23.7 \%$ nymphs and $58.1 \%$ adults). The most common mixed infections were with $A$. phagocytophilum (31.1\% larval pools, $17.5 \%$ nymphs and $52.7 \%$ adults), whereby co-infections of $A$. phagocytophilum and Theileria spp. prevailed (Table 4). They were detected in $16.2 \%$ larval pools, $15.2 \%$ nymphs and $38.7 \%$ adults, and occurred in ticks collected from all cervid species. Mixed infections with four microorganisms, namely $A$. phagocytophilum, Theileria, Rickettsia and Borrelia occurred exclusively in ticks attached to roe deer.

Proportions of I. ricinus infected with A. phagocytophilum alone and co-infected with Theileria spp. depended on the tick stage. Significant differences were revealed between nymphs and adults $\left(\chi^{2}=14.759, P<0.001\right)$, but not between larvae and nymphs or adults. Proportions of single and mixed infections with A. phagocytophilum depended on the cervid host in larvae and nymphs, but not in adults (larval pools: $X^{2}=7.755, P=0.021$; nymphs: $X^{2}=6.127 ; P=0.045$ ). Overall proportions of uninfected $I$. ricinus and those infected with single and multiple pathogens did not depend on the cervid host $\left(X^{2}=5.568, P=0.234\right)$, but depended on the tick developmental stage $\left(\chi^{2}=47.321, P<0.001\right)$. The proportions differed significantly between larvae and nymphs $\left(\chi^{2}=\right.$ 18.698, $P<0.001)$ and between nymphs and adults
$\left(X^{2}=40.468, P<0.001\right)$, but not between larvae and adults $\left(\chi^{2}=3.456, P=0.178\right)$.

In H. concinna, mixed infection with A. phagocytophilum and Babesia sp. was detected in a single larva collected from an A. phagocytophilum-infected mouflon.

\section{Anaplasma phagocytophilum variants}

By analysing the variation of the $16 \mathrm{~S}$ rRNA gene of $A$. phagocytophilum from ungulates, five variants showed identity with corresponding sequences deposited in the GenBank database. Four of these variants were designated according to Schorn et al. [88] and Silaghi et al. [89] as "Y", "S", "W", and "B" (Table 5). Importantly, variant "B" from wild boar was found to be identical with the sequence of the HGA agent (AY886761). A fifth sequence obtained from mouflon (MF061301) was not identical with any of the abovementioned variants and was designated as variant "Q". It showed $100 \%$ identity with database entries of $A$. phagocytophilum isolated from the spleen of sika deer (KU705189), red deer (KU705138), and mouflon (KU705120) in Germany as well as from blood and spleen of red deer in the Czech Republic (EU839849) and in Slovenia (AF481852), respectively. Out of 16 selected engorged I. ricinus larvae, amplification of $16 \mathrm{~S}$ rRNA gene was successful for eight ticks feeding on roe and fallow deer. Only in a single case, the $16 S$ rRNA gene sequence variant " $\mathrm{S}$ " identified in a larva corresponded with that of its fallow deer host, whereas in another larva of the same fallow deer, the variant "W" was identified. In three larvae sampled from three other fallow deer, the variant "S" was identified in one and the variant " $\mathrm{B}$ " in the remaining two larvae. The variant " $\mathrm{X}$ " was found in three larvae from roe deer.

Analysis of A. phagocytophilum groEL gene sequences derived from this study (see Additional file 2: Table S2) revealed the presence of two groEL gene variants in ungulates that are designated as ecotype I and II according to the classification by Jahfari et al. [20]. The variant identified in wild boar showed $100 \%$ identity to the HGA agent from human blood from Slovenia (AF033101). Amplification of the partial groEL gene was only successful for two I. ricinus larvae from fallow deer (MG773209 and MG773210) that were not identical with the sequence identified in the host. In the phylogenetic tree constructed 


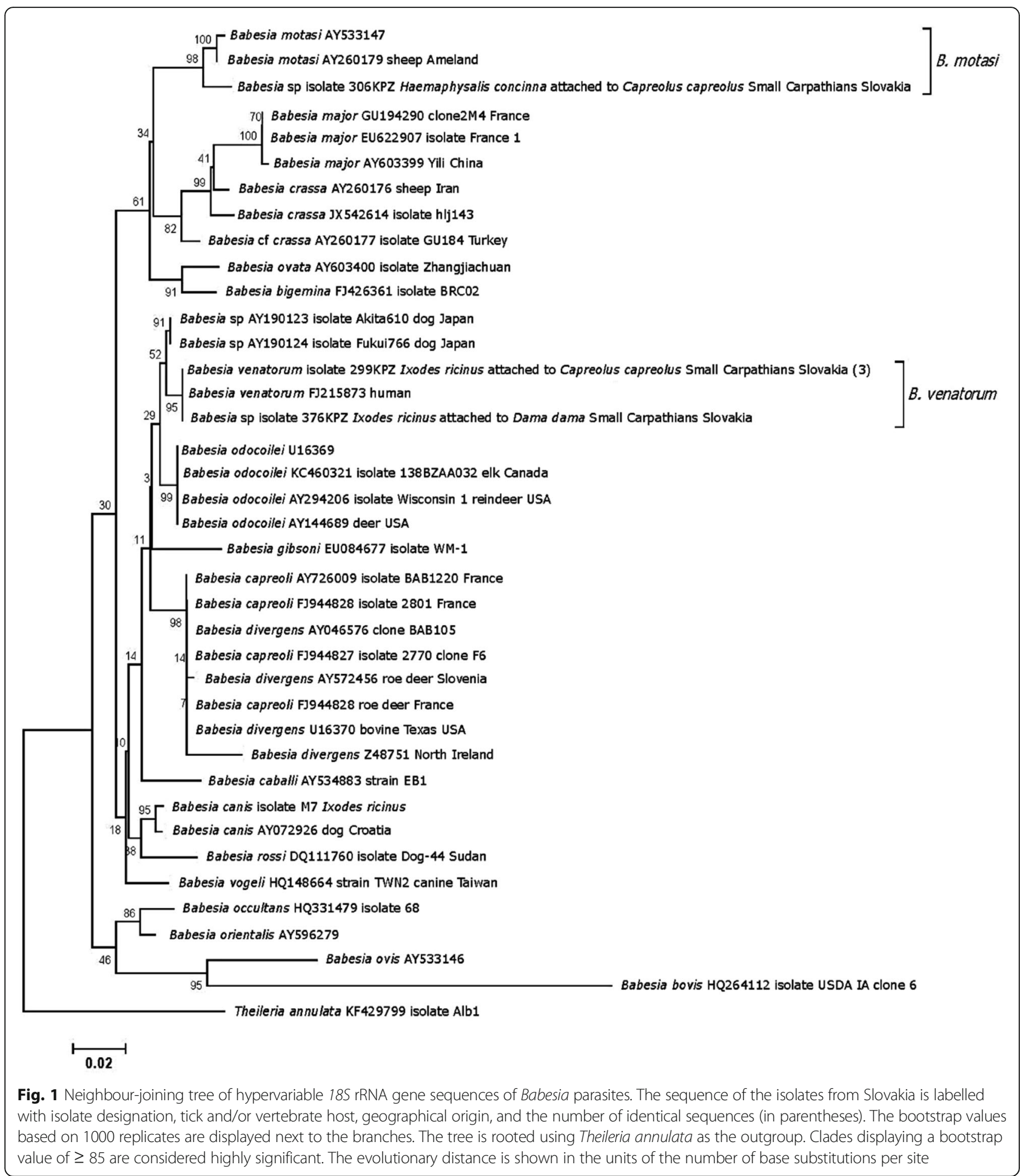

by using the 12 obtained sequences and the 42 groEL partial gene sequences retrieved from GenBank, the two sequences from roe deer formed a cluster together with sequences from roe deer from Germany, France, Slovenia and questing I. ricinus ticks from Slovenia and eastern Slovakia. The sequences from the other ungulates and engorged I. ricinus ticks clustered together with sequences from other sources, including that from a human patient (Additional file 3: Figure S2).

Analysis of piroplasmid sequences

A phylogenetic tree inferred from aligned Babesia $18 S$ rRNA gene sequences showed the identity of a Babesia 
Table 4 Single and mixed infections in Ixodes ricinus ticks infesting free-living ungulates

\begin{tabular}{|c|c|c|c|c|c|c|c|}
\hline \multirow[t]{2}{*}{ Infection (Pathogens) } & \multirow{2}{*}{$\begin{array}{l}\text { Tick } \\
\text { stage }\end{array}$} & \multirow{2}{*}{$\begin{array}{l}\text { No. of } \\
\text { samples }(\%)^{a}\end{array}$} & \multicolumn{5}{|l|}{ Host } \\
\hline & & & Roe deer & Red deer & Fallow deer & Mouflon & Wild boar \\
\hline \multicolumn{8}{|l|}{ Uninfected } \\
\hline & $L$ & 7 pools & & $\times$ & $\times$ & & \\
\hline & $\mathrm{N}$ & 49 & $x$ & $x$ & $x$ & & $\times$ \\
\hline & M & 3 & & $x$ & $x$ & & \\
\hline & Subtotal & $59(17.1)$ & & & & & \\
\hline \multicolumn{8}{|l|}{ Single infections } \\
\hline \multirow[t]{5}{*}{$A p$} & $L$ & 26 pools & $\times$ & $x$ & $x$ & $x$ & \\
\hline & N & 65 & $\times$ & $x$ & $x$ & $\times$ & \\
\hline & $\mathrm{F}$ & 23 & & $x$ & $x$ & $\times$ & \\
\hline & M & 8 & & & & & \\
\hline & Subtotal & $122(35.5)$ & & & & & \\
\hline \multirow[t]{4}{*}{ Th } & $L$ & 5 pools & $\times$ & $\times$ & & & \\
\hline & $\mathrm{N}$ & 15 & $\times$ & $\times$ & $\times$ & & \\
\hline & $\mathrm{F}$ & 5 & $x$ & & $\times$ & & \\
\hline & Subtotal & $25(7.3)$ & & & & & \\
\hline$R h$ & $\mathrm{~N}$ & $3(0.9)$ & $\times$ & & $\times$ & & \\
\hline $\mathrm{Ba}$ & $\mathrm{N}$ & $1(0.3)$ & $\times$ & & & & \\
\hline Bval & N & $1(0.3)$ & & & $\times$ & & \\
\hline Bgar & $\mathrm{N}$ & $1(0.3)$ & & & $\times$ & & \\
\hline \multicolumn{8}{|l|}{ Mixed infections } \\
\hline \multirow[t]{5}{*}{$A p+T h$} & $L$ & 12 pools & $\times$ & & $x$ & & \\
\hline & N & 27 & $x$ & $x$ & $x$ & & \\
\hline & $\mathrm{F}$ & 29 & & $x$ & $x$ & & \\
\hline & M & 7 & & $x$ & $\times$ & & \\
\hline & Subtotal & 75 (21.8) & & & & & \\
\hline \multirow[t]{3}{*}{$A p+B v$} & L & 1 pool & $x$ & & & & \\
\hline & $\mathrm{F}$ & 1 & & & $\times$ & & \\
\hline & Subtotal & $2(0.6)$ & & & & & \\
\hline$A p+C N M$ & $\mathrm{~F}$ & $1(0.3)$ & $\times$ & & & & \\
\hline \multirow[t]{3}{*}{$A p+C b$} & N & 4 & $x$ & & & & \\
\hline & $\mathrm{F}$ & 1 & & & & $\times$ & \\
\hline & subtotal & $5(1.4)$ & & & & & \\
\hline \multirow[t]{4}{*}{$A p+R s p$} & L & 6 pools & $x$ & & & & \\
\hline & $N$ & 1 & $x$ & & & & \\
\hline & M & 1 & $x$ & & & & \\
\hline & Subtotal & $8(2.3)$ & & & & & \\
\hline \multirow[t]{3}{*}{$A p+R h$} & N & 4 & & & $x$ & & \\
\hline & $\mathrm{F}$ & 1 & & & & $\times$ & \\
\hline & Subtotal & $5(1.4)$ & & & & & \\
\hline$A p+R m$ & L & 1 pool (0.3) & & & $\times$ & & \\
\hline$T h+B v$ & L & 1 pool (0.3) & $x$ & & & & \\
\hline$T h+C N M$ & $N$ & $1(0.3)$ & $x$ & & & & \\
\hline$T h+R h$ & $L$ & 2 pools & $x$ & & $x$ & & \\
\hline
\end{tabular}


Table 4 Single and mixed infections in Ixodes ricinus ticks infesting free-living ungulates (Continued)

\begin{tabular}{|c|c|c|c|c|c|c|c|}
\hline \multirow[t]{2}{*}{ Infection (Pathogens) } & \multirow{2}{*}{$\begin{array}{l}\text { Tick } \\
\text { stage }\end{array}$} & \multirow{2}{*}{$\begin{array}{l}\text { No. of } \\
\text { samples (\%) }\end{array}$} & \multicolumn{5}{|l|}{ Host } \\
\hline & & & Roe deer & Red deer & Fallow deer & Mouflon & Wild boar \\
\hline & $N$ & 1 & & & $\times$ & & \\
\hline & Subtotal & $3(0.9)$ & & & & & \\
\hline$A p+T h+C N M$ & $\mathrm{~F}$ & 2 & $x$ & & $x$ & & \\
\hline$A P+B v+R s p$ & $L$ & 1 pool & $x$ & & & & \\
\hline \multirow[t]{3}{*}{$A p+T h+R s p$} & L & 6 pools & $\times$ & & & & \\
\hline & N & 2 & $x$ & $x$ & & & \\
\hline & Subtotal & $8(2.3)$ & & & & & \\
\hline \multirow[t]{5}{*}{$A p+T h+R h$} & L & 3 pools & & $x$ & & & \\
\hline & N & 1 & & & $x$ & & \\
\hline & $\mathrm{F}$ & 8 & & & $\times$ & & \\
\hline & M & 1 & & & $x$ & & \\
\hline & Subtotal & $13(3.8)$ & & & & & \\
\hline$A p+T h+R m$ & L & 1 pool (0.3) & & & $\times$ & & \\
\hline$A p+T h+C b$ & $\mathrm{~F}$ & $1(0.3)$ & & & $\times$ & & \\
\hline$A p+R s p+C b$ & L & 1 pool (0.3) & & & $x$ & & \\
\hline$A p+T h+B v a l$ & M & $1(0.3)$ & & & $\times$ & & \\
\hline$A p+T h+R s p+B v a l$ & L & 1 pool (0.3) & $x$ & & & & \\
\hline$A p+T h+R h+B g a r$ & N & $1(0.3)$ & $x$ & & & & \\
\hline
\end{tabular}

Abbreviations: $\times$, presence; Ap, Anaplasma phagocytophilum; Th, Theileria spp.; Bv, Babesia venatorum; CNM, "Candidatus Neoehrlichia mikurensis"; Rsp, Rickettsia sp.; Rh, Rickettsia helvetica; Rm, Rickettsia monacensis; Ba, Borrelia afzelii; Bgar, Borrelia garinii; Bval, Borrelia valaisiana; Cb, Coxiella burnetii; L, larva; N, nymph; F, female; M, male anfection prevalence (in \%), the total number of analysed samples was 344 (74 pools of larvae, 177 nymphs, 72 females, 21 males)

isolate identified in a roe deer-attached $H$. concinna tick with $B$. motasi, with the highly significant bootstrap support of 98 (Fig. 1). Four other sequences, three amplified from $I$. ricinus ticks that had been attached to roe deer and one amplified from an I. ricinus attached to a fallow deer, were placed with the highly significant bootstrap support of 95 into the B. venatorum clade. Importantly, all four sequences were identical with the sequence FJ215873 of B. venatorum isolated from a human patient that has been originally isolated and described as Babesia sp. EU1 [36].

To assess the species identity of Theileria isolates, the Theileria $18 S$ rRNA gene sequences were compared with corresponding sequences available on GenBank by phylogenetic analysis. In the inferred tree, Theileria sp. 1 and 2 sequences segregated jointly with Theileria capreoli isolated from red deer in Spain, and two other Theileria spp. isolated from red and roe deer, respectively, into a single clade. Interestingly, Theileria sp. 1 isolates were only found in red deer whereas Theileria sp. 2 isolates were only present in roe deer suggesting that these are two Theileria species with different host specificity (Additional file 4: Figure S3). Analysed 185 rRNA gene sequences of Theileria and Babesia species are listed with their GenBank accession numbers in Additional file 1: Table S3.

\section{Discussion}

Changes in land use and urbanisation increase the frequency of encounters between wildlife and domestic animals and humans that, in turn, increase the risk of contracting zoonotic diseases [18, 90-92]. Slovakia is covered, in part, by forests [64] with abundant populations of wildlife, including large game animals [93]. The present study explored associations of free-living ungulates with ticks and tick-borne microorganisms in deciduous forests of the Small Carpathian Mountains, comprising recreational areas (Bratislava Forest Park) and hunting districts.

\section{Infestation of ungulates with ticks}

Free-living ungulates are important for maintenance of tick populations $[11,94]$ and serve as a reservoir and/or spillover hosts for tick-borne microorganisms [32, 95]. With respect to their wide home range, they can transport ticks of all developmental stages over long distances and thus contribute to the natural maintenance of transmission cycles of tick-borne agents and their dispersal [11, 16, 96, 97]. Ixodes ricinus dominated among ticks collected from the hunted ungulates in our study, which is in line with the occurrence and abundance of questing ticks in the study area [98]. Contrary to the expected, exclusively larvae and nymphs but no adults of $H$. concinna 
Table 5165 rRNA and groEL gene sequence variants of A. phagocytophilum in free-living ungulates and engorged ticks

\begin{tabular}{|c|c|c|c|}
\hline Species/ Isolate code & Sex/Age & Variant $165 \mathrm{rRNA}^{\mathrm{a}}$ & Variant groE $\left.\right|^{b}$ \\
\hline Capreolus capreolus / 18SPZ & $\delta / ?$ & Y & $\|$ \\
\hline Capreolus capreolus / 55SPZ & $\hat{\delta} / 1$ year & Y & $\|$ \\
\hline Cervus elaphus / 19SPZ & $0 / 3$ years & S & । \\
\hline Cervus elaphus / 21SPZ & $\hat{\delta} /$ juvenile & W & । \\
\hline Dama dama / 25SPZ & q $/ 2$ years & S & I \\
\hline Dama dama / 51SPZ & Q / juvenile & S & । \\
\hline Ovis musimon / 10SPZ & $\delta / ?$ & $Q^{e}$ & । \\
\hline Ovis musimon / 63SPZ & $\hat{0} / 3$ years & W & । \\
\hline Sus scrofa / 13SPZ & $\delta / ?$ & B & । \\
\hline Sus scrofa / 43SPZ & q $/ ?$ & B & । \\
\hline I. ricinus larva from C. capreolus / 190KPZ & & $x$ & na \\
\hline I. ricinus larva from C. capreolus / 193KPZ & & $x$ & na \\
\hline I. ricinus larva from C. capreolus / 236KPZ & & $x$ & na \\
\hline I. ricinus larva from D. dama / $129 \mathrm{KPZ}$ & & S & । \\
\hline I. ricinus larva from D. dama / $158 \mathrm{KPZ}$ & & W & 1 \\
\hline I. ricinus larva from D. dama / $180 \mathrm{KPZ}$ & & S & na \\
\hline I. ricinus larva from D. dama / 268KPZ & & B & na \\
\hline I. ricinus larva from D. dama / 382KPZ & & B & na \\
\hline
\end{tabular}

${ }^{a}$ Nomenclature according to Schorn et al. [88] and Silaghi et al. [89]

${ }^{\mathrm{b}}$ Nomenclature according to Jahfari et al. [20]

${ }^{\mathrm{c} S P Z}$, spleen from game

${ }^{\mathrm{d}} \mathrm{KPZ}$, ticks from game

${ }^{\mathrm{e}}$ The sequence did not match with the variants described in Schorn et al. [88] or Silaghi et al. [89] and was submitted to GenBank (accession number MF061301); na, not amplified

were found, though similarly as for I. ricinus, small mammals and ground-dwelling passerine birds are considered as the main hosts of their subadult stages and ungulates are hosts of adults $[99,100]$. Tick numbers, the ratio between the abundance of developmental stages and data on seasonality of tick infestation were biased in our study because in the majority of cases only small portions of the skin restricted to a few body parts were provided and could be examined. In addition to legs and hoofs, whole skins were available only from a few fallow deer individuals from which we were able to gather relatively high numbers of ticks compared to the other game species. The majority of engorged and semi-engorged adult and subadult ticks found on the whole skin of fallow deer were attached to groins, axillae, and the belly, which is in contrast to the attachment patterns of tick developmental stages reported for roe and red deer [13, 15]. Nevertheless, our results support previous findings on the role of cervids and mouflon as hosts and vehicles for I. ricinus $[13,15,58,63,94,96]$ and the individual variation of tick burdens [11]. In contrast to reports from the Netherlands [63], but in line with findings from Poland [58], the infestation rate of wild boars was very low in our study $(5.1 \%$ - only a single crawling I. ricinus nymph and one $D$. reticulatus male were found on their legs).
We assume that the epidermis in this part of the wild boar's body is too hard and the fur too thick to provide places favourable for tick attachment. Moreover, wild boars have been reported to be mainly hosts of Dermacentor marginatus [101], a species that has not been recorded in the study area [98], whereas $D$. reticulatus could be found only sporadically [67, personal observations].

\section{Anaplasma phagocytopilum in ungulates and engorged ticks}

All examined game species were infected with $A$. phagocytophilum. The infection rates were high: $96.1 \%$ in cervids; $88.9 \%$ in mouflon; and $28.2 \%$ in wild boar. The presence of this bacterium in game has frequently been reported from different regions of Europe [19, 95], with varying prevalences depending on the host species, examined tissue, site, but also on the sensitivity of the detection method used. The infection rates of $100 \%$ in red deer, $95.4 \%$ in fallow deer, and $92.9 \%$ in roe deer estimated from our study are higher than values previously reported from Slovakia: red deer 17.5-53.1\% [24, 57, 102]; fallow deer $66.7 \%$ [24], and roe deer $50-77 \%[24,57,102,103]$. The infection rates determined in this study are in the upper range of those confirmed by PCR in cervids from other countries of mainland Europe, where the values 
in red deer ranged between $1.5-86 \%$ [89, 104-114], in fallow deer between 1.5-72.5\% [42, 105, 106, 108, 110, $112,115,116]$ and in roe deer between 9.6-98.9\% [38, 42, $89,105-113,117-120]$. The $88.9 \%$ infection rate in mouflon is higher than the values previously reported from Slovakia [57] and other European countries, where the prevalences ranged from $4 \%$ to $74.4 \%$ [42, 106, 110, 111]. The lower infection rate in wild boar compared to that estimated in cervids and mouflon supports former findings from Slovakia $(0-16.7 \%)[24,57,112,121]$ as well as from other sites in central and western Europe (0$14.3 \%)[28,58,105,106,110,122-127]$. However, it is necessary to note that, in addition to geographical location and habitat, the reported variations of prevalence could be due to the application of molecular detection methods of different sensitivity.

Ixodes ricinus is considered to represent the common vector of A. phagocytophilum in Europe [8] and was the most numerous tick species collected from cervids in our study, with an average prevalence of 27.2\% MLE in larvae, $58.3 \%$ in nymphs and $94.3 \%$ in adults. The bacterial DNA was previously detected in questing I. ricinus nymphs and adults from the Small Carpathian forests [67]. The high prevalence in both cervids and attached $I$. ricinus ticks suggests that cervids may serve as reservoir hosts of $A$. phagocytophilum and are a source of infection for vector ticks in the studied region. However, the number of studies in which engorged I. ricinus from cervids were examined for infection with $A$. phagocytophilum along with their hosts is limited. For example, no $A$. phagocytophilum was detected in $I$. ricinus collected from roe deer in Slovakia and Poland [112, 118], but in other sites in Poland, $12.5 \%$ and $9 \%$ of ticks from roe deer and red deer, respectively, were found to be infected [58]. For engorged ticks from cervids in Italy, a $31.2 \%$ prevalence [113] or $29.9 \%$ positive pools [128] were found, but no information on the tick developmental stage was given. In another study from Italy, a prevalence of $11 \%$ and $5.4 \%$ was detected for nymphs/adults and larvae, respectively [129]. The prevalence in adult ticks feeding on cervids in Italy (7.3\%) [116] and Poland (22.7\%) [108] was lower than in our study, whereas it was comparable with the $86.1 \%$ prevalence reported from a site in Germany, where the infection rate of roe deer was as high as 98.7\% [38]. Anaplasma phagocytophilum was also detected in engorged $H$. concinna larvae and nymphs feeding on infected roe deer and fallow deer. However, questing $H$. concinna from the study area were not found to be infected [67] suggesting that this species is not a competent vector of the bacterium and that the bacterial DNA originated from the ingested host blood.

Based on specific genetic markers, the presence of a wide variety of $A$. phagocytophilum variants associated with particular groups of hosts was found to circulate in wildlife and ticks in Europe [19, 95, 130, 131]. Cervids are suggested to be the main reservoir hosts, whereby roe deer probably maintain specific strains that are not pathogenic for humans or domestic livestock while red deer could be reservoirs for strains associated with disease in domestic ruminants $[26,104,106]$. According to recent findings, however, roe deer can be co-infected with two to three distinct genetic variants, including those associated with domestic ruminants [132]. Human pathogenic $A$. phagocytophilum strains have been detected in wild boars suggesting their potential reservoir role for the HGA agent [28, 122, 123]. Four ecotypes of A. phagocytophilum that differ in host ranges and zoonotic potential have been identified based on groEL gene sequences [20], whereby ecotype I is associated with the broadest host range and I. ricinus ticks and also includes strains causing disease in domestic animals and humans. Ecotype II was found to be associated with roe deer and does not include zoonotic strains. Sequence analysis of selected ungulate isolates from our study revealed five different variants of the partial $16 S$ rRNA gene and two groEL gene variants, whereby the results agree with previously published findings. Identification of the $16 \mathrm{~S}$ rRNA gene variant "B" (the prototype variant of the HGA agent) and of groEL sequences that are $100 \%$ identical with the HGA agent isolated from human blood from Slovenia (AF033101) in wild boars suggests that they could be potential reservoirs of the HGA strain in the study area. To our knowledge, this is the first confirmed occurrence of this strain in wild boars from Slovakia, whereas sequences of former GenBank isolates from Slovak wild boars were identical with sequences from wild ruminants, horses, dogs or wild boar and showed a lower degree of identity with the HGA sequence [24, 121]. However, further research is required to find out if wild boars in Slovakia are involved in the enzootic cycle of $A$. phagocytophilum variants pathogenic to humans. In roe deer, $16 S$ rRNA variant "Y" $[88,89]$ and groEL ecotype II sequences [20] were identified, which have been detected mainly in this species and have not been associated with clinical cases of granulocytic anaplasmosis [20, 38, 42, 89]. Sequences from red deer, fallow deer, and mouflon (16S rRNA variants "S" and "W", groEL ecotype I) showed a high degree of identity with sequences from wild ruminants, cattle, horses, hedgehogs, dogs, or foxes, i.e. variants that can cause disease in domestic animals.

Four $16 S$ rRNA gene variants were identified in engorged $I$. ricinus larvae: variant "X", associated with roe deer $[88,89]$ in larvae from roe deer, and variants "S", "W" and "B" as well as groEL ecotype I in larvae from fallow deer. Interestingly, but in agreement with results for roe deer from Germany [38], not all $16 S$ rRNA 
gene variants from engorged ticks matched the variant detected in the corresponding hosts. The reasons for this variation, however, remain unclear. Nevertheless, our results support the role of cervids as natural reservoirs for several $A$. phagocytophilum genetic variants in Slovakia out of which some may be of veterinary importance.

\section{Piroplasmids in ungulates and engorged ticks}

Previous studies have suggested the reservoir role of European cervids and caprines for different Babesia species, including the zoonotic $B$. venatorum and $B$. divergens [38-40, 42, 104, 111, 114, 119, 133, 134]. Infestation of cervids with ticks that carry potentially zoonotic strains of Babesia spp. is common [38, 58, 129, 135-137]. In the study area, infection with babesiae has previously been confirmed in questing $I$. ricinus (B. venatorum, B. capreoli and $B$. odocoilei), for which vector competence was confirmed for B. venatorum [138], and $H$. concinna, infected with Babesia spp. infective for small ruminants [79]. In the present study, the examined ungulates were Babesianegative, whereas $B$. venatorum was identified in engorged I. ricinus larvae attached to roe and fallow deer and $B$. motasi in $H$. concinna larvae attached to roe deer. Considering the possibility of transovarial transmission of babesiae, our results suggest that natural foci of different Babesia spp., including zoonotic strains, may be present in the studied region, but further research is required to elucidate their associations with reservoir hosts. The finding of the B. motasi species in $H$. concinna is of particular interest and supports recent results and theories on the wide distribution of piroplasmids transmitted by this tick in Europe and Asia [31, 79, 139], and the possible role of migratory birds in their spread [140].

In contrast to the absence of Babesia infections, a relatively high infection rate with Theileria was determined in the examined cervids, corroborating findings from southwestern Hungary, where exclusively Theileria spp.; however, no Babesia spp. were identified in large game animals [141]. The presence of piroplasmids of the genus Theileria has been reported in wildlife from different regions of mainland Europe [40, 42, 47-51, 58, 134, 141], including a record from red deer from Slovakia dating back to 1958 [45]. Theileria spp. have not been associated with zoonotic infections, but chronic asymptomatic theileriosis has been observed in European cervids that may serve as infection reservoirs, with prevalences ranging up to $100 \%$ in some populations $[49,50,134,141]$. To the best of our knowledge, this study provides the first molecular evidence of Theileria in cervids and the first report of Theileria infections in roe and fallow deer from Slovakia. Theileria spp. were also detected in engorged $I$. ricinus and $H$. concinna ticks feeding on infected animals, corroborating findings from other regions of Europe with abundant populations of I. ricinus and occurrence of $H$. concinna $[49,50]$. In a phylogenetic analysis, two $18 S$ rRNA gene sequence variants obtained from cervids and engorged ticks clustered together with sequences designated as Theileria sp. and/or T. capreoli. This cluster included Theileria sp. 3185/02 from roe deer, Spain [47] and Theileria sp. BAB1158, Spain. Also, these variants showed an identity of $99-100 \%$ to Theileria sp. ZS T04 detected in red deer in Poland [48], Austria [50] and Germany [42], and also to Theileria spp. identified in questing $H$. concinna from Hungary [139] and Slovakia [79]. Importantly, the two genotypes Theileria sp. 1 and 2 can be distinguished based on a single characteristic mutation that corresponds to those recently reported in Theileria genotypes elaphy CE1 (exclusively identified in red and fallow deer) and capreoli CE1 (exclusively identified in roe deer) from Hungary, respectively [141]. These data strongly support the finding of Hornok et al. [141] that Theileria spp. of cervids comprises a complex of at least two or even more species.

The modes of transmission and vectors of Theileria spp. associated with European cervids are largely unknown and may depend on the abundance and dominance of tick species and the population density of cervids in a particular area [141]. Either I. ricinus [47-49] or $H$. concinna $[50,141]$ have been suggested as possible vectors, but alternative mechanisms, e.g. transplacental transmission, should also be taken into account, especially in cervid populations with high infection rates [48]. The following findings may indicate that $H$. concinna could be the vector of Theileria in the study area: (i) cervids are hosts for both $I$. ricinus and $H$. concinna ticks; (ii) the high Theileria infection rate in cervids; (iii) the detection of Theileria only in I. ricinus feeding on cervids, but not in questing ticks [79]; (vi) detection of identical Theileria genotypes in cervids, questing $H$. concinna, $H$. concinna attached to cervids and even in a rodent-attached $H$. concinna female [79]. Nevertheless, alternative mechanisms of transmission may also exist. Thus, a more in-depth molecular analysis of the detected Theileria genotypes and their associations with cervid hosts and vectors is needed.

\section{The occurrence of other bacteria in engorged ticks}

In this study, SFG rickettsiae (R. helvetica and $R$. monacensis), Coxiella burnetii, "Ca. N. mikurensis" and $B$. burgdorferi (s.l.) were detected only in engorged $I$. rici$n u s$ ticks. Sporadic infections with $R$. helvetica, previously reported from roe deer from Slovakia [57] or roe deer and wild boar from the Netherlands [59], were not confirmed for the study area. However, our results are consistent with other studies reporting the presence of SFG rickettsiae in I. ricinus feeding on free-living ungulates [38, 128, 129, 142]. Moreover, rickettsial infection in tick larvae feeding on uninfected hosts as well as a 
comparable prevalence of SFG rickettsiae in the examined engorged $I$. ricinus and in questing ticks from the study area [143] suggest that large ungulates play a role in the dispersion of infected ticks, but are not involved in the natural circulation of SFG rickettsiae in the Small Carpathian forests.

Coxiella burnetii infections have been detected, e.g. in red deer [114], but not in wild boar from central Italy [127], and in red deer from the Iberian Peninsula [56], suggesting a reservoir role of red deer. In eastern Slovakia, exposure to C. burnetii was previously determined in game animals (up to $28.3 \%$ fallow deer and $29.6 \%$ mouflon) by routine seroscreening [144, 145]. However, there is no evidence of the involvement of large ungulates in the life-cycle of the pathogen in this country [146, 147]. Natural infections with C. burnetii have been detected in ticks (questing or feeding on different hosts) from different countries $[53,148]$ including Slovakia [74, 147, 149, 150], whereas transmission of the $\mathrm{Q}$ fever agent to humans via a tick bite is rare [53]. Based on our detections of C. burnetii in all developmental stages of $I$. ricinus that were collected from large ungulates we assume that similarly as for SFG rickettsiae, ungulates serve only as vehicles for the transport of infected ticks. The same seems to apply to " $C a$. N. mikurensis" and B. burgdorferi (s.l.) that were previously detected in questing ticks from the study area $[73,151]$ and in a low portion of the examined engorged $I$. ricinus, but not in ungulates. This is in line with previous findings for "Ca. N. mikurensis", for which rodents are suggested as reservoirs [152]. Free-living ungulates and $I$. ricinus feeding on them have previously been found infected with $B$. burgdorferi (s.l.) to a very low extent and are considered to be incompetent reservoirs for the pathogen. At high densities, they may even cause a decline in the density of infected ticks [63, 153].

\section{Mixed infections in ungulates and ticks}

In our study, mixed infections with A. phagocytophilum and Theileria were found in cervids and prevailed in engorged I. ricinus, whereas co-infections with two to four different microorganisms were detected only in the ticks. The only mixed infection in $H$. concinna was with A. phagocytopilum and Babesia sp. Infections of free-living ungulates and their ticks with multiple microorganisms are common in natural habitats of Europe and have been reported, e.g. from Poland [58, 119], Germany $[38,42]$, Austria [111], Italy [114, 127, 128] and Switzerland [39]. Double infections with $A$. phagocytophilum and Theileria were found, e.g. in cervids from western Poland [58], but the reported co-infection rates $(12.3 \%$ in roe deer and $28 \%$ in red deer) were lower than in our study.
In general, infections of ticks with multiple pathogens can result in co-transmission of various combinations of tick-borne microorganisms to vertebrate hosts, which may have severe implications for human and animal health [154-156]. We assume that co-transmission of the detected microorganisms to ungulates by ticks does not occur in the study area, or it may occur to a very low extent (e.g. co-transmission of B. venatorum and $A$. phagocytopilum by $I$. ricinus). This assumption is supported by the following findings: (i) ungulates were found infected only with $A$. phagocytophilum and Theileria and are probably reservoirs of these microorganisms; (ii) $I$. ricinus is the competent vector for $A$. phagocytophilum and $B$. venatorum, but probably not for Theileria; (iii) ungulates, particularly cervids, may be reservoirs of $B$. venatorum, whereas for the other recorded microorganisms their reservoir competence is questionable (SFG rickettsiae, C. burnetii) or has not been confirmed (B. burgdorferi and "Ca. N. mikurensis"); (iv) $H$. concinna is probably the vector of Theileria and B. motasi, but its vector competence for $A$. phagocytophilum has not been confirmed. On the other hand, ungulates seem to play an essential role in the dispersal of ticks that carry and may transmit or co-transmit microorganisms with possible impact on the health of domestic animals and pets [i.e. A. phagocytophilum, Babesia spp., C. burnetii and B. burgdorferi (s.l.)], and humans [i.e. the HGA agent, $B$. venatorum, " $\mathrm{Ca}$. N. mikurensis", SFG rickettsiae, C. burnetii and B. burgdorferi (s.l.)]. However, further research is necessary to more profoundly characterise the genotypes of the microorganisms that circulate in the study area and their pathogenicity to humans, domestic animals and pets. Positive interactions (mutualism or interactions with host symbionts), as well as competition between microorganisms co-infecting the vector ticks and the vertebrate hosts, need to be explored. Such studies have the potential to reveal (i) decreases or increases of disease severity, (ii) an increased host susceptibility to other infections, and (iii) the resulting complications for diagnosis and treatment.

\section{Conclusions}

The results of the study demonstrate that $A$. phagocytophilum and Theileria circulate in natural foci of the Small Carpathian Mountains and free-living ungulates are probably their reservoirs. Also, free-living ungulates seem to be involved in the transport and dispersal of ticks infected with several microorganisms including zoonotic tick-borne pathogens, which points to the risk of exposure of hunters and tourists to multiple infections. Further studies are necessary to gain a better knowledge of the epidemiology of the tick-borne microorganisms occurring in the deciduous forests of southwestern Slovakia. 


\section{Additional files}

Additional file 1: Figure S1. Map of the study area. Hunting districts were located in the Small Carpathian Mountains, between Bratislava and Dubová pri Modre (see red line in the lower panel). (PDF 659 kb)

Additional file 2: Table S1. Primers and probes $(P)$ used in $P C R$ reactions and references (numbers in bold) where specific conditions of the PCR reactions are described. Table S2. GenBank accession numbers of $A$. phagocytophilum 165 rRNA and groEL gene sequences identified in spleen and engorged ticks from free-living ungulates. Table S3. GenBank accession numbers of piroplasmid 185 rRNA gene sequences identified in the spleen of free-living ungulates and engorged ticks. (PDF 275 kb)

Additional file 3: Figure S2. Molecular phylogenetic analysis of the partial groEL gene of Anaplasma phagocytophilum derived from freeranging ungulates and engorged Ixodes ricinus larvae from southwestern Slovakia. (PDF 62 kb)

Additional file 4: Figure S3. Neighbour-joining tree of hypervariable 185 rRNA gene sequences of Theileria parasites using neighbour-joining. (PDF 332 kb)

\section{Acknowledgements}

The authors thank the association of hunters, namely Mr Hrnčír (district Modra), Mr Puškáč (district Pezinok), Mr Bílik (district Harmónia), Mr Pokorný (district Záhorská Bystrica), and Mr Novák (district Bratislava) for providing organs and ticks from hunted animals. We thank Ryanne Jaarsma (RIVM) for excellent technical assistance in the laboratory.

\section{Funding}

The study was funded by EU grant FP7-261504 EDENext and is catalogued by the EDENext Steering Committee as EDENext398 (http://www.edenext.eu) The contents of this publication are the sole responsibility of the authors and do not necessarily reflect the views of the European Commission. Financial support by grants of the Slovak Research and Development Agency (APW DO7RP0014-11, APW 0280-12) is also acknowledged. The work of ZH was supported, in part, by EurNegVec COST Action TD1303. This contribution is also the result of using infrastructure acquired by the project implementation (code ITMS: 26240220044), supported by the Research \& Development Operational Programme funded by the ERDF.

\section{Availability of data and materials}

The datasets used and/or analysed during the current study are available from the corresponding author upon request. New partial DNA sequences were submitted to the GenBank database under the accession numbers MF061301, MF061229-MF061238, MG773209, MG773210 and KX470610KX470626.

\section{Authors' contributions}

EK and MK designed the study, analysed the data and drafted the manuscript RC gained and provided game tissue and tick samples. EK identified the ticks. $\mathrm{ZH}, \mathrm{LM}$ and LMI processed the samples. MF developed and validated the duplex qPCR for Babesia spp. ZH, ES, LMI, MF and LM performed PCRs. LS, ZH, MK and HS carried out phylogenetic analyses. EK, MK, ES, HS and $L S$ revised the manuscript. All authors read and approved the final manuscript.

\section{Ethics approval and consent to participate}

The conducted study complies with current laws of the Slovak Republic. There is no conflict of interest with species conservation guidelines. The game animals were killed for hunting reasons during the legal hunting season and not specifically for this study. Therefore, approval of the ethics committee was not required.

\section{Consent for publication}

Not applicable.

\section{Competing interests}

The authors declare that they have no competing interests.

\section{Publisher's Note}

Springer Nature remains neutral with regard to jurisdictional claims in published maps and institutional affiliations.

\section{Author details}

${ }^{1}$ Institute of Zoology, Slovak Academy of Sciences, Dúbravská cesta 9, 84506 Bratislava, Slovakia. ${ }^{2}$ Institute of Virology, Biomedical Research Center, Slovak Academy of Sciences, Dúbravská cesta 9, 84505 Bratislava, Slovakia. ${ }^{3}$ Široká 22, 83107 Bratislava, Slovakia. ${ }^{4}$ Laboratory for Zoonoses and Environmental Microbiology, National Institute for Public Health and Environment, 9 Antonie van Leeuwenhoeklaan, P.O. Box 1, Bilthoven, The Netherlands. ${ }^{5}$ Instituto de Patobiologia, CICVyA, INTA-Castelar, 1686 Hurlingham, Prov. de Buenos Aires, Argentina. ${ }^{6}$ CONICET, C1033AAJ Ciudad Autónoma de Buenos Aires, Argentina.

Received: 10 May 2018 Accepted: 20 August 2018

Published online: 03 September 2018

\section{References}

1. Randolph SE. The shifting landscape of tick-borne zoonoses: tick-borne encephalitis and Lyme borreliosis in Europe. Philos Trans R Soc Lond B Biol Sci. 2001;356:1045-56.

2. Randolph SE. Tick-borne disease systems emerge from the shadows: the beauty lies in molecular detail, the message in epidemiology. Parasitology. 2009;136:1403-13.

3. Heyman P, Cochez C, Hofhuis A, van der Giessen J, Sprong H, Porter SR, et al. A clear and present danger: tick-borne diseases in Europe. Expert Rev Anti Infect Ther. 2010;8:33-50.

4. Salman M, Tarrés-Call J. Ticks and tick-borne diseases. Geographical distribution and control strategies in the Euro-Asia region. Wallingford: CABI; 2013.

5. Medlock JM, Hansford KM, Bormane A, Derdakova M, Estrada-Peña A, George J-C, et al. Driving forces for changes in geographical distribution of Ixodes ricinus ticks in Europe. Parasit Vectors. 2013;6:1.

6. Sonenshine DE, Roe RM. Biology of Ticks, Vol. 1. Oxford: Oxford University Press; 2014

7. Rizzoli A, Silaghi C, Obiegala A, Rudolf I, Hubálek Z, Földvári G, et al. Ixodes ricinus and its transmitted pathogens in urban and peri-urban areas in Europe: new hazards and relevance for public health. Front Public Health. 2014;2:251.

8. Bircher AJ, Hofmeier KS, Link S, Heijnen I. Food allergy to the carbohydrate galactose-alpha-1,3-galactose (alpha-gal): four case reports and a review. Eur J Dermatol. 2017;27:3-9.

9. Bowmann A, Nuttall P, editors. Ticks: Biology, Disease and Control. New York: Cambridge University Press; 2008

10. Hofmeester TR, Coipan EC, Van Wieren SE, Prins HHT, Takken W, Sprong H. Few vertebrate species dominate the Borrelia burgdorferi s.I. life-cycle. Environ Res Lett. 2016;11:1-16.

11. Vor $T$, Kiffner $C$, Hagedorn $P$, Niedrig $M$, Rühe F. Tick burden on European roe deer (Capreolus capreolus). Exp Appl Acarol. 2010;51:405-17.

12. Tagliapietra V, Rosà R, Arnoldi D, Cagnacci F, Capelli G, Montarsi F, et al. Saturation deficit and deer density affect questing activity and local abundance of Ixodes ricinus (Acari, Ixodidae) in Italy. Vet Parasitol. 2011; 183:114-24

13. Kiffner C, Lödige C, Alings M, Vor T, Rühe F. Attachment site selection of ticks on roe deer, Capreolus capreolus. Exp Appl Acarol. 2011;53:79-94.

14. Gilbert L, Maffey GL, Ramsay SL, Hester AJ. The effect of deer management on the abundance of Ixodes ricinus in Scotland. Ecol Appl. 2012;22:658-67.

15. Mysterud A, Hatlegjerde IL, Sørensen OJ. Attachment site selection of life stages of Ixodes ricinus ticks on a main large host in Europe, the red deer (Cervus elaphus). Parasit Vectors. 2014;7:510.

16. Pfäffle M, Littwin N, Muders SV, Petney TN. The ecology of tick-borne disease Int J Parasitol. 2013;43:1059-77.

17. Billinis C. Wildlife diseases that pose a risk to small ruminants and their farmers. Small Ruminant Res. 2013;110:67-70.

18. Mackenstedt $U$, Jenkins $D$, Romig $T$. The role of wildlife in the transmission of parasitic zoonoses in peri-urban and urban areas. Int J Parasitol Parasit Wildl. 2015:4:71-9.

19. Stuen S, Granquist EG, Silaghi C. Anaplasma phagocytophilum - a widespread multihost pathogen with highly adaptive strategies. Front Cell Infect Microbiol. 2013;3:31. 
20. Jahfari S, Coipan C, Fonville M, van Leeuwen AD, Hengeveld P, Heylen D, et al. Circulation of four Anaplasma phagocytophilum ecotypes in Europe. Parasit Vectors. 2014;7:365.

21. Strle F. Human granulocytic ehrlichiosis in Europe. Int J Med Microbiol. 2004;293 S37:27-35.

22. Stuen S. Anaplasma phagocytophilum - the most widespread tick-borne infection in animals in Europe. Vet Res Commun. 2007;31(Suppl. 1):79-84.

23. Stuen S, Pettersen KS, Granquist EG, Bergström K, Bown KJ, Birtles RJ. Anaplasma phagocytophilum variants in sympatric red deer (Cervus elaphus) and sheep in southern Norway. Ticks Tick Borne Dis. 2013;4:197-201.

24. Víchová B, Majláthová V, Nováková M, Stanko M, Hviščová I, Pangrácová L, et al. Anaplasma infections in ticks and reservoir host in Slovakia. Infect Genet Evol. 2014;22:265-72.

25. Baráková I, Derdáková M, Carpi G, Rosso F, Collini M, Tagliapietra V, et al. Genetic and ecologic variability among Anaplasma phagocytophilum strains in northern Italy. Emerg Infect Dis. 2014;20:1082-4.

26. Huhn C, Winter C, Wolfsperger T, Wüppenhorst N, Strašek Smrdel K, Skuballa J, et al. Analysis of the population structure of Anaplasma phagocytophilum using multilocus sequence typing. PLoS One. 2014;9:e93725.

27. Dugat $T$, Chastagner A, Lagrée A-C, Petit E, Durand B, Thierry S, et al. A new multiple-locus variable-number tandem repeat analysis reveals different clusters for Anaplasma phagocytophilum circulating in domestic and wild ruminants. Parasit Vectors. 2014;7:439.

28. Michalik J, Stańczak J, Cieniuch S, Racewicz M, Sikora B, Dabert M. Wild boars as hosts of human-pathogenic Anaplasma phagocytophilum variants. Emerg Infect Dis. 2012;18:2094-5.

29. Silaghi C, Pfister K, Overzier E. Molecular investigation for bacterial and protozoan tick-borne pathogens in wild boars (Sus scrofa) from southern Germany. Vector Borne Zoonotic Dis. 2014;14:371-3.

30. Galindo RC, Ayllón N, Strašek Smrdel K, Boadella M, Beltrán-Beck B, Mazariegos M, et al. Gene expression profile suggests that pigs (Sus scrofa) are susceptible to Anaplasma phagocytophilum but control infection. Parasit Vectors. 2012;5:181.

31. Schnittger L, Rodriguez AE, Florin-Christensen M, Morrison D. Babesia: a world emerging. Infect Genet Evol. 2012;12:1788-809.

32. Yabsley MJ, Shock BC. Natural history of zoonotic Babesia: role of wildlife reservoirs. Int J Parasitol Parasit Wildl. 2013;2:18-31.

33. Malandrin L, Jouglin M, Sun $Y$, Brisseau N, Chauvin A. Redescription of Babesia capreoli (Enigk and Friedhoff, 1962) from roe deer (Capreolus capreolus): isolation, cultivation, host specificity, molecular characterisation and differentiation from Babesia divergens. Int J Parasitol. 2010;40:277-84.

34. Zintl A, Mulcahy G, Skerrett HE, Taylor SM, Gray JS. Babesia divergens: a bovine blood parasite of veterinary and zoonotic importance. Clin Microbiol Rev. 2003; 16:622-36.

35. Gray J, Zintl A, Hildebrandt A, Hunfeld K, Weiss L. Zoonotic babesiosis: overview of the disease and novel aspects of pathogen identity. Ticks Tick Borne Dis. 2010;1:3-10.

36. Herwaldt BL, Caccio S, Gherlinzoni F, Aspock H, Slemenda SB, Piccaluga P, et al. Molecular characterization of a non-Babesia divergens organism causing zoonotic babesiosis in Europe. Emerg Infect Dis. 2003;9:942-8.

37. Häselbarth K, Tenter AM, Brade V, Krieger G, Hunfeld KP. First of human babesios is in Germany - clinical presentation and molecular characterization of the pathogen. Int J Med Microbiol. 2007;297:197-204

38. Overzier E, Pfister K, Herb I, Mahling M, Bock G Jr, Silaghi C. Detection of tick-borne pathogens in roe deer (Capreolus capreolus), in questing ticks (Ixodes ricinus), and in ticks infesting roe deer in southern Germany. Ticks Tick Borne Dis. 2013:4:320-8.

39. Michel AO, Mathis A, Ryser-Degiorgis M-P. Babesia spp. in European wild ruminant species: parasite diversity and risk factors for infection. Vet Res. 2014;45:65.

40. Zanet S, Trisciuoglio A, Bottero E. Garcia Fernández de Mera I, Gortazar C, Carpignano MG, Ferroglio E. Piroplasmosis in wildlife: Babesia and Theileria affecting free-ranging ungulates and carnivores in the Italian Alps. Parasit Vectors. 2014;7:70

41. Andersson MO, Bergvall UA, Chirico J, Christensson M, Lindgren P-R, Nordström J, Kjellander P. Molecular detection of Babesia capreoli and Babesia venatorum in wild Swedish roe deer, Capreolus capreolus. Parasit Vectors. 2016;9:221.

42. Kauffmann M, Rehbein S, Hamel D, Lutz W, Heddergott M, Pfister K, Silaghi C. Anaplasma phagocytophilum and Babesia spp. in roe deer (Capreolus capreolus), fallow deer (Dama dama) and mouflon (Ovis musimon) in Germany. Mol Cell Probes. 2017;31:46-54.
43. Tampieri MP, Galuppi R, Bonoli C, Cancrini G, Moretti A, Pietrobelli M. Wild ungulates as Babesia hosts in northern and central Italy. Vector Borne Zoonotic Dis. 2008:8:667-74.

44. Friedhoff KT. Tick-borne diseases of sheep and goats caused by Babesia, Theileria or Anaplasma spp. Parassitologia. 1997;39:99-109.

45. Černý V. Theileriafunde beim europäischen Hirsch im Gebiet von Topolčianky (Slowakei). Biologia (Bratislava). 1958;13:509-13.

46. Hinaidy HK. Blutparasiten der wildlebenden Wiederkäuer Österreichs. Zentralbl Veterinarmed. 1987;34:81-97.

47. García-Sanmartín J, Aurtenetxe O, Barral M, Marco I, Lavin S, García-Pérez AL, Hurtado A. Molecular detection and characterization of piroplasms infecting cervids and chamois in northern Spain. Parasitology. 2007;134:391-8.

48. Sawczuk M, Maciejewska A, Skotarczak B. Identification and molecular characterization of Theileria sp. infecting red deer (Cervus elaphus) in northwestern Poland. Eur J Wildl Res. 2008;54:225-30.

49. Galuppi R, Aureli S, Bonoli C, Caffara M, Tampieri MP. Detection and molecular characterization of Theileria sp. in fallow deer (Dama dama) and ticks from an Italian natural preserve. Res Vet Sci. 2011;91:110-5.

50. Fuehrer H-P, Biro N, Harl J, Worliczeka HL, Beiglböck C, Farkas R, et al. Molecular detection of Theileria sp. ZS TO4 in red deer (Cervus elaphus) and questing Haemaphysalis concinna ticks in eastern Austria. Vet Parasitol. 2013;197:653-7.

51. Pereira A, Parreira R, Nunes M, Casadinho A, Vieira ML, Campino L, Maia C. Molecular detection of tick-borne bacteria and protozoa in cervids and wild boars from Portugal. Parasit Vectors. 2016;9:251.

52. Pereira A, Parreira R, Cotão AJ, Nunes M, Vieira ML, Azevedo F, et al. Tickborne bacteria and protozoa detected in ticks collected from domestic animals and wildlife in central and southern Portugal. Ticks Tick Borne Dis. 2018;9:225-34.

53. Maurin M, Raoult D. Q fever. Clin Microbiol Rev. 1999;12:518-53.

54. Rijks JM, Roest HIJ, van Tulden PW, Kik MJL, Gröne A. Infection in roe deer during Q fever epidemic, the Netherlands. Emerg Infect Dis. 2011;17:2369-71.

55. Ohlson A, Malmsten J, Frössling J, Bölske G, Aspán A, Dalin A-M, Lindberg A. Surveys on Coxiella burnetii infections in Swedish cattle, sheep, goats and moose. Acta Vet Scand. 2014;56:39.

56. González-Barrio D, Velasco Ávila AL, Boadella M, Beltrán-Beck B, Barasona JÁ, et al. Host and environmental factors modulate the exposure of free-ranging and farmed red deer (Cervus elaphus) to Coxiella burnetii. Appl Environ Microbiol. 2015;81:6223-31.

57. Stefanidesova K, Kocianova E, Boldis V, Kostanova Z, Kanka P, Nemethova D, Spitalska E. Evidence of Anaplasma phagocytophilum and Rickettsia helvetica infection in free-ranging ungulates in central Slovakia. Eur J Wildl Res. 2008; 54:519-24.

58. Skotarczak B, Adamska M, Sawczuk M, Maciejewska A, Wodecka B, Rymaszewska A. Coexistence of tick-borne pathogens in game animals and ticks in western Poland. Veterinarni Medicina. 2008;53:668-75.

59. Sprong $H$, Wielinga PR, Fonville $M$, Reusken $C$, Brandenburg $A H$, Borgsteede $F$, et al. Ixodes ricinus ticks are reservoir hosts for Rickettsia helvetica and potentially carry flea-borne Rickettsia species. Parasit Vectors. 2009;2:41.

60. Faria AS, Paiva-Cardoso MD, Nunes M, Carreira T, Vale-Gonçalves HM, Veloso $\mathrm{O}$, et al. First detection of Borrelia burgdorferi sensu lato DNA in serum of the wild boar (Sus scrofa) in Northern Portugal by nested-PCR. EcoHealth. 2015; 12:183-7.

61. Kurtenbach K, Sewell HS, Ogden NH, Randolph SE, Nuttall PA. Serum complement sensitivity as a key factor in Lyme disease ecology. Infect Immun. 1998;66:1248-51.

62. Rosef O, Paulauskas A, Radzijevskaja J. Prevalence of Borrelia burgdorferi sensu lato and Anaplasma phagocytophilum in questing Ixodes ricinus ticks in relation to the density of wild cervids. Acta Vet Scand. 2009;51:47.

63. Pacilly FCA, Benning ME, Jacobs F, Leidekker J, Sprong H, Van Wieren SE, Takken W. Blood feeding on large grazers affects the transmission of Borrelia burgdorferi sensu lato by Ixodes ricinus. Ticks Tick Borne Dis. 2014;5:810-7.

64. Atlas Krajiny Slovenskej Republiky. http://geo.enviroportal.sk/atlassr/ Accessed 20 Sep 2017.

65. Siuda K. Kleszcze Polski (Acari: Ixodida) Systematyka i rozmieszczenie. Warszawa: Polskie Towarzystwo Parazytologiczne; 1993.

66. Courtney JW, Kostelnik LM, Zeidner NS, Massung RF. Multiplex real-time PCR for detection of Anaplasma phagocytophilum and Borrelia burgdorferi. J Clin Microbiol. 2004;42:3164-8.

67. Svitálková Z, Haruštiaková D, Mahríková L, Berthová L, Slovák M, Kocianová E, Kazimírová M. Anaplasma phagocytophilum prevalence in ticks and 
rodents in an urban and natural habitat in south-western Slovakia. Parasit Vectors. 2015:8:276.

68. Massung RF, Slater K, Owens JH, Nicholson WL, Mather TN, Solberg VB, Olson JG. Nested PCR assay for detection of granulocytic ehrlichiae. J Clin Microbiol. 1998:36:1090-5.

69. Overzier E, Pfister K, Thiel C, Herb I, Mahling M, Silaghi C. Anaplasma phagocytophilum in questing lxodes ricinus ticks: comparison of prevalences and partial 165 rRNA gene variants in urban, pasture, and natural habitats. Appl Environ Microbiol. 2013;79:1730-4.

70. Alberti A, Zobba R, Chessa B, Addis MF, Sparagano O, Pinna Parpaglia ML, et al. Equine and canine Anaplasma phagocytophilum strains isolated on the island of Sardinia (Italy) are phylogenetically related to pathogenic strains from the United States. Appl Environ Microbiol. 2005:71:6418-22.

71. Jahfari S, Fonville M, Hengeveld P, Reusken C, Scholte EJ, Takken W, et al. Prevalence of Neoehrlichia mikurensis in ticks and rodents from north-west Europe. Parasit Vectors. 2012;5:74.

72. Silaghi C, Woll D, Mahling M, Pfister K, Pfeffer M. Candidatus Neoehrlichia mikurensis in rodents in an area with sympatric existence of the hard ticks Ixodes ricinus and Dermacentor reticulatus, Germany. Parasit Vectors. 2012;5: 285.

73. Hamšíková Svitálková Z, Haruštiaková D, Mahríková L, Mojšová M, Berthová L, Slovák M, et al. Candidatus Neoehrlichia mikurensis in ticks and rodents from urban and natural habitats of South-Western Slovakia. Parasit Vectors. 2016;9:2.

74. Špitalská E, Kocianová E. Detection of Coxiella burnetii in ticks collected in Slovakia and Hungary. Eur J Epidemiol. 2003;18:263-6.

75. Regnery RL, Spruill CL, Plikaytis BD. Genotypic identification of rickettsiae and estimation of intraspecies sequence divergence for portions of two rickettsial genes. J Bacteriol. 1991;173:1576-89.

76. Špitalská E, Stanko M, Mošanský L, Kraljik J, Miklisová D, Mahríková L, et al. Seasonal analysis of Rickettsia species in ticks in and agricultural site of Slovakia. Exp Appl Acarol. 2016;68:315-24.

77. Derdáková M, Beati L, Pet'ko B, Stanko M, Fish D. Genetic variability within Borrelia burgdorferi sensu lato genospecies established by PCR-single-strand conformation polymorphism analysis of the rrfA-rrlB intergenic spacer in Ixodes ricinus ticks from the Czech Republic. Appl Environ Microbiol. 2003;69:509-16.

78. Casati S, Sager H, Gern L, Piffaretti JC. Presence of potentially pathogenic Babesia sp. for human in Ixodes ricinus in Switzerland. Ann Agric Environ Med. 2006;13:65-70.

79. Hamšíková Z, Kazimírová M, Haruštiaková D, Mahríková L, Slovák M, Berthová L, et al. Babesia spp. in ticks and wildlife in different habitat types of Slovakia. Parasit Vectors. 2016;9:292.

80. Øines $\varnothing$, Radzijevskaja J, Paulauskas A, Rosef O. Prevalence and diversity of Babesia spp. in questing Ixodes ricinus ticks from Norway. Parasit Vectors. 2012:5:156.

81. Tamura K, Stecher G, Peterson D, Filipski A, Kumar S. MEGA6: Molecular Evolutionary Genetics Analysis version 6.0. Mol Biol Evol. 2013;30:2725-9.

82. Saitou N, Nei M. The neighbor-joining method: a new method for reconstructing phylogenetic trees. Mol Biol Evol. 1987:4:406-25.

83. Nei M, Kumar S. Molecular Evolution and Phylogenetics. New York: Oxford University Press; 2000.

84. Tamura K. Estimation of the number of nucleotide substitutions when there are strong transition-transversion and $\mathrm{G}+\mathrm{C}$-content biases. Mol Biol Evol. 1992;9:678-87

85. Kumar S, Stecher G, Li M, Knyaz C, Tamura K. MEGA X: Molecular Evolutionary Genetics Analysis across computing platforms. Mol Biol Evol. 2018;35:1547-9.

86. Biggerstaff BJ. PooledInfRate, Version 4.0: a Microsoft ${ }^{\circledR}$ Office Excel@ Add-In to compute prevalence estimates from pooled samples. Fort Collins, CO, USA: Centers for Disease Control and Prevention; 2009.

87. Hammer $\varnothing$, Harper DAT, Ryan PD. PAST: Paleontological Statistics software package for education and data analysis. Paleontol Electron. 2001;4:1-9.

88. Schorn S, Pfister K, Reulen H, Mahling M, Manitz J, Thiel C, Silaghi C. Prevalence of Anaplasma phagocytophilum in Ixodes ricinus in Bavarian public parks, Germany. Ticks Tick Borne Dis. 2011;2:196-203.

89. Silaghi C, Hamel D, Thiel C, Pfister K, Passos LM, Rehbein S. Genetic variants of Anaplasma phagocytophilum in wild caprine and cervid ungulates from the Alps in Tyrol, Austria. Vector Borne Zoonotic Dis. 2011;11:355-62.

90. Martin C, Pastoret PP, Brochier B, Humblet MF, Saegerman C. A survey of the transmission of infectious diseases/infections between wild and domestic ungulates in Europe. Vet Res. 2011;42:70.
91. Alexander NS, Massei G, Wint W. The European distribution of Sus scrofa. Model outputs from the project described within the poster - where are all the boars? An attempt to gain a continental perspective. Open Health Data. 2016:4:e1.

92. Tomassone L, Berriatua E, De Sousa R, Duscher GG, Mihalca AD, Silaghi C, et al. Neglected vector-borne zoonoses in Europe: into the wild. Vet Parasitol. 2018;251:17-26

93. ForestPortal - lesnícky portál. Národné lesnícke centrum (NLC), Zvolen. http://www.forestportal.sk/lesne-hospodarstvo/polovnictvo/Documents/. Accessed 20 Jan 2018.

94. Kiffner C, Lödige C, Alings M, Vor T, Rühe F. Abundance estimation of Ixodes ticks (Acari: Ixodidae) on roe deer (Capreolus capreolus). Exp Appl Acarol. 2010;52:73-84.

95. Dugat T, Lagrée A-C, Maillard R, Boulouis H-J, Haddad N. Opening the black box of Anaplasma phagocytophilum diversity: current situation and future perspectives. Front Cell Infect Microbiol. 2015;5:61.

96. Qviller L, Risnes-Olsen N, Bærum KM, Meisingset EL, Loe LE, Ytrehus B, et al. Landscape-level variation in tick abundance relative to seasonal migration in red deer. PLoS One. 2013;8:e71299.

97. Hofmeester TR, Sprong H, Jansen PA, Prins HHT, van Wieren SE. Deer presence rather than abundance determines the population density of the sheep tick, Ixodes ricinus, in Dutch forests. Parasit Vectors. 2017;10:433.

98. Kazimírová M, Hamšíková Z, Kocianová E, Marini G, Mojšová M, Mahríková L, et al. Relative density of host-seeking ticks in different habitat types of south-western Slovakia. Exp Appl Acarol. 2016;69:205-24.

99. Nosek J. The ecology, bionomics and behaviour of Haemaphysalis (Haemaphysalis) concinna tick. Z Parasitenkd. 1971;36:233-41.

100. Hornok S, Kováts D, Csörgő T, Meli ML, Gönczi E, Hadnagy Z, et al. Birds as potential reservoirs of tick-borne pathogens: first evidence of bacteraemia with Rickettsia helvetica. Parasit Vectors. 2014;7:128.

101. Ortuňo A, Quesada M, López S, Miret J, Cardeňosa N, Castella J, et al. Prevalence of $R$. slovaca in Dermacentor marginatus ticks removed from wild boar (Sus scrofa) in northeastern Spain. Ann N Y Acad Sci. 2006;1078:324-7.

102. Štefanidesová K, Špitalská E, Krkoš I, Smetanová E, Kocianová E. Anaplasma phagocytophilum and other tick-bacteria in wild animals in western Slovakia. Biologia. 2011;66:1087-90.

103. Štefanidesová K, Hamšíková Z, Krkoš I, Smetanová E, Špitalská E. Anaplasma phagocytophilum - a pathogen circulating in wild animals in natural foci of western Slovakia. In: Zoonoses - Protection of Public and Animal Health 5th Scientific Congress. Slovak Medical University, Bratislava, Slovakia. 2016. p. 263-5.

104. Cézanne R, Mrowietz N, Eigner B, Duscher GG, Glawischnig W, Fuehrer H-P. Molecular analysis of Anaplasma phagocytophilum and Babesia divergens in red deer (Cervus elaphus) in western Austria. Mol Cell Probes. 2017;31:55e58.

105. Hulinska D, Votypka J, Plch J, Vlcek E, Valesova M, Bojar M, et al. Molecular and microscopical evidence of Ehrlichia spp. and Borrelia burgdorferi sensu lato in patients, animals and ticks in the Czech Republic. Microbiologica. 2002;25:437-48.

106. Hulínská D, Langrová K, Pejčoch M, Pavlásek I. Detection of Anaplasma phagocytophilum in animals by real-time polymerase chain reaction. APMIS. 2004;112:239-47.

107. Polin H, Hufnagl P, Haunschmid R, Gruber F, Ladurner G. Molecular evidence of Anaplasma phagocytophilum in Ixodes ricinus ticks and wild animals in Austria. J Clin Microbiol. 2004;42:2285-6.

108. Michalik J, Stanczak J, Racewicz M, Cieniuch S, Sikora B, Szubert-Kruszynska A, Grochowalska R. Molecular evidence of Anaplasma phagocytophilum infection in wild cervids and feeding Ixodes ricinus ticks from west-central Poland. Clin Microbiol Infect. 2009;15(Suppl. 2):81-3.

109. Petrovec M, Bidovec A, Sumner JW, Nicholson WL, Childs JE, AvsicZupanc T. Infection with Anaplasma phagocytophila in cervids from Slovenia: evidence of two genotypic lineages. Wien Klin Wochenschr. 2002;114:641-7.

110. Zeman P, Pecha M. Segregation of genetic variants of Anaplasma phagocytophilum circulating among wild ruminants within a Bohemian forest (Czech Republic). Int J Med Microbiol. 2008;298(S1):203-10.

111. Silaghi C, Hamel D, Pfister K, Rehbein S. Babesia species and co-infection with Anaplasma phagocytophilum in free-ranging ungulates from Tyrol (Austria). Tierärztliche Mschr Vet Med Austria. 2011;98:268-74.

112. Hapunik J, Víchová B, Karbowiak G, Wita I, Bogdaszewski M, Pet'ko B. Wild and farm breeding cervids infections with Anaplasma phagocytophilum. Ann Agric Environ Med. 2011;18:73-7. 
113. Di Domenico M, Pascucci I, Curini V, Cocco A, Dall'Acqua F, Pompilii C, Cammà C. Detection of Anaplasma phagocytophilum genotypes that are potentially virulent for human in wild ruminants and Ixodes ricinus in central Italy. Ticks Tick Borne Dis. 2016;7:782-7.

114. Ebani W, Rocchigiani G, Bertelloni F, Nardoni S, Leoni A, Nicoloso S, Mancianti F. Molecular survey on the presence of zoonotic arthropod-borne pathogens in wild red deer (Cervus elaphus). Comp Immunol Microbiol Infect Dis. 2016;47:77-80.

115. Ebani W, Cerri D, Fratini F, Ampola M, Andrean E. Anaplasma phagocytophilum infection in a fallow deer (Dama dama) population in a preserve of central Italy. New Microbiol. 2007;30:161-5.

116. Veronesi F, Galuppi R, Tampieri MP, Bonoli C, Mammoli R, Piergili Fioretti D. Prevalence of Anaplasma phagocytophilum in fallow deer (Dama dama) and feeding ticks from an Italy preserve. Res Vet Sci. 2011;90:40-3.

117. Liz JS, Sumner JW, Pfister K, Brossard M. PCR detection and serological evidence of granulocytic ehrlichial infection in roe deer (Capreolus capreolus) and chamois (Rupicapra rupicapra). J Clin Microbiol. 2002;40:892-7.

118. Adamska M, Skotarczak B. Wild game as a reservoir of Anaplasma phagocytophilum in north-western Poland. Wiad Parazytol. 2007;53:103-7.

119. Welc-Falęciak R, Werszko J, Cydzik K, Bajer A, Michalik J, Behnke JM. Coinfection and genetic diversity of tick-borne pathogens in roe deer from Poland. Vector Borne Zoonotic Dis. 2013;13:277-88.

120. Scharf W, Schauer S, Freyburger F, Petrovec M, Schaarschmidt-Kiener D, Liebisch G, et al. Distinct host species correlate with Anaplasma phagocytophilum ankA gene clusters. J Clin Microbiol. 2011;49:790-6.

121. Reiterová K, Špilovská S, Blaňarová L, Derdáková M, Čobádiová A, Hisira V. Wild boar (Sus scrofa) - reservoir host of Toxoplasma gondii, Neospora caninum and Anaplasma phagocytophilum in Slovakia. Acta Parasitol. 2016. 61:255-60.

122. Petrovec M, Sixl W, Schweiger R, Mikulasek S, Elke L, Wust G, et al. Infections of wild animals with Anaplasma phagocytophila in Austria and the Czech Republic. Ann N Y Acad Sci. 2003;990:103-6.

123. Strasek Smrdel K, Bidovec A, Malovrh T, Petrovec M, Duh D, Avsic Zupanc T. Detection of Anaplasma phagocytophilum in wild boar in Slovenia. Clin Microbiol Infect. 2009;15(Suppl 2):50-2.

124. Žele D, Avberšek J, Gruntar I, Ocepek M, Vengušt G. Evidence of Anaplasma phagocytophilum in game animals from Slovenia. Acta Vet Hung. 2012;60:441-8.

125. Nahayo A, Bardiau M, Volpe R, Pirson J, Paternostre J, Fett T, Linde A. Molecular evidence of Anaplasma phagocytophilum in wild boar (Sus scrofa) in Belgium. BMC Vet Res. 2014;10:80.

126. Kiss T, Cadar D, Krupaci FA, Bordeanu AD, Spînu M. Prevalence of Anaplasma phagocytophilum infection in European wild boar (Sus scrofa) populations from Transylvania, Romania. Epidemiol Infect. 2014;142:246-50.

127. Ebani W, Bertelloni F, Cecconi G, Sgorbini M, Cerri D. Zoonotic tick-borne bacteria among wild boars (Sus scrofa) in central Italy. Asian Pac J Trop Dis. 2017;7:141-3.

128. Ebani W, Bertelloni F, Turchi B, Filogari D, Cerri D. Molecular survey of tickborne pathogens in ixodid ticks collected from hunted wild animals in Tuscany, Italy. Asian Pac J Trop Med. 2015;8:714-7.

129. Baráková I, Derdáková M, Selyemová D, Chvostáč M, Špitalská E, Rosso F, et al. Tick-borne pathogens and their reservoir hosts in northern Italy. Ticks Tick Borne Dis. 2018;9:164-70.

130. Woldehiwet Z. The natural history of Anaplasma phagocytophilum. Vet Parasitol. 2010;167:108-22.

131. Battilani M, De Arcangeli S, Balboni A, Dondi F. Genetic diversity and molecular epidemiology of Anaplasma. Infect Genet Evol. 2017;49:195-211.

132. Jouglin M, Chagneau S, Faille F, Verheyden H, Bastian S, Malandrin L. Detecting and characterizing mixed infections with genetic variants of Anaplasma phagocytophilum in roe deer (Capreolus capreolus) by developing an ankA cluster-specific nested PCR. Parasit Vectors. 2017;10:377.

133. Duh D, Petrovec M, Bidovec A, Avsic-Zupanc T. Cervids as babesiae hosts, Slovenia. Emerg Infect Dis. 2005;1 1:1121-3.

134. Sawczuk M, Maciejewska A, Adamska M, Skotarczak B. Roe deer (Capreolus capreolus) and red deer (Cervus elaphus) as a reservoir of protozoans from Babesia and Theileria genus in north-western Poland. Wiad Parazytol. 2005; 51:243-7.

135. Hilpertshauser H, Deplazes P, Schnyder M, Gern L, Mathis A. Babesia spp. identified by PCR in ticks collected from domestic and wild ruminants in southern Switzerland. Appl Environ Microbiol. 2006;72:6503-7.
136. Lempereur L, Lebrun M, Cuvelier P, Sépult G, Caron Y, Saegerman C, et al. Longitudinal field study on bovine Babesia spp. and Anaplasma phagocytophilum infections during a grazing season in Belgium. Parasitol Res. 2012;110:1525-30.

137. Lempereur L, Wirtgen M, Nahayo A, Caron Y, Shiels B, Saegerman C, et al. Wild cervids are host for tick vectors of Babesia species with zoonotic capability in Belgium. Vector Borne Zoonotic Dis. 2012;12:275-80.

138. Becker CA, Bouju-Albert A, Jouglin M, Chauvin A, Malandrin L. Natural transmission of zoonotic Babesia spp. by Ixodes ricinus ticks. Emerg Infect Dis. 2009;15:320-2.

139. Hornok S, Takács N, Kontschán J, György Z, Micsutka A, Iceton S, et al. Diversity of Haemaphysalis-associated piroplasms of ruminants in centraleastern Europe, Hungary. Parasit Vectors. 2015;8:627.

140. Flaisz B, Sulyok KM, Kováts D, Kontschán J, Csörgő T, Csipak Á, et al. Babesia genotypes in Haemaphysalis concinna collected from birds in Hungary reflect phylogeographic connections with Siberia and the Far East. Ticks Tick Borne Dis. 2017:8:666-70

141. Hornok S, Sugár L, Horváth G, Kovács T, Micsutka A, Gönczi E, et al. Evidence for host specificity of Theileria capreoli genotypes in cervids. Parasit Vectors. 2017;10:473.

142. Stańczak J, Racewicz M, Michalik J, Cieniuch S, Sikora B, Skoracki M. Prevalence of infection with Rickettsia helvetica in feeding ticks and their hosts in western Poland. Eur Soc Clin Microbiol Infect Dis. 2009; 15(Suppl. 2):328-9,

143. Minichová L, Hamšíková Z, Mahríková M, Slovák M, Kocianová E, Kazimírová $\mathrm{M}$, et al. Molecular evidence of Rickettsia spp. in ixodid ticks and rodents in suburban, natural and rural habitats in Slovakia. Parasit Vectors. 2017:10:158.

144. Trávniček M, Čisláková L, Kocianová E, Miško J. Pancák J. Q horúčka a chlamydióza u danielov a muflónov. In: Zborník referátov z vedeckej konferencie, sekcia: Aktuálne problémy epizootológie a infektológie. Košice, Slovakia; 1999. p. 28-30.

145. Dorko E, Rimárová K, Pilipčinec E, Trávniček M. Prevalence of Coxiella burneti antibodies in wild ruminants in Kavečany zoo, Košice, eastern Slovakia. Ann Agric Environ Med. 2009;16:321-4.

146. Řeháček J. Prevalence of Q fever in Czechoslovakia. Cs Epidemiol Microbiol Immunol. 1976;25:58-63.

147. Řeháček J, Úrvölgyi J, Kocianová E, Sekeyová Z, Vavreková M, Kováčová E. Extensive examination of different tick species for infestation with Coxiella burnetii in Slovakia. Eur J Epidemiol. 1991;7:299-303.

148. Sprong H, Tijsse-Klasen E, Langelaar M, De Bruin A, Fonville M, Gassner F, et al. Prevalence of Coxiella burnetii in ticks after a large outbreak of $\mathrm{Q}$ fever. Zoonoses and Public Health. 2012;59:69-75.

149. Smetanová K, Schwarzová K, Kocianová E. Detection of Anaplasma phagocytophilum, Coxiella burnetii, Rickettsia spp., and Borrelia burgdorferi s.l. in ticks, and wild-living animals in western and middle Slovakia. Ann N Y Acad Sci. 2006:1078:312-5.

150. Berthová L, Slobodník V, Slobodník R, Olekšák M, Sekeyová Z, Svitálková Z, et al. The natural infection of birds and ticks feeding on birds with Rickettsia spp. and Coxiella burnetii in Slovakia. Exp Appl Acarol. 2016;68:299-314.

151. Hamšíková Z, Coipan C, Mahríková L, Minichová L, Sprong H, Kazimírová M. Borrelia miyamotoi and co-infection with Borrelia afzelii in Ixodes ricinus ticks and rodents from Slovakia. Microb Ecol. 2017;73:1000-8.

152. Obiegala A, Silaghi C. Candidatus Neoehrlichia mikurensis - recent insights and future perspectives on clinical cases, vectors, and reservoirs in Europe. Curr Clin Micro Rpt. 2018;5:1.

153. van Wieren SE, Hofmeester TR. 6. The role of large herbivores in Ixodes ricinus and Borrelia burgdorferi s.l. dynamics. In: Braks MAH, van Wieren SE, Takken W, Sprong H, editors. Ecology and Prevention of Lyme Borreliosis and Control of Vector-borne Diseases Volume 4. Wageningen: Academic Publishers. 2016. p. 75-89.

154. Ginsberg HS. Potential effects of mixed infections in ticks on transmission dynamics of pathogens: comparative analysis of published records. Exp Appl Acarol. 2008:46:29-41.

155. Diuk-Wasser MA, Vannier E, Krause PJ. Coinfection by Ixodes tick-borne pathogens: ecological, epidemiological, and clinical consequences. Trends Parasitol. 2016;32:30-42.

156. Moutailler S, Valiente Moro C, Vaumourin E, Michelet L, Tran FH, Devillers E, et al. Co-infection of ticks: the rule rather than the exception. PLoS Negl Trop Dis. 2016;10:e0004539. 